\title{
Late Pleistocene-Holocene Volcanism on the Kamchatka Peninsula, Northwest Pacific Region
}

\author{
Vera Ponomareva, Ivan Melekestsev and Olga Braitseva \\ Institute of Volcanology and Seismology, Petropavlovsk-Kamchatsky, Russia \\ Tatiana Churikova ${ }^{1}$ \\ Geowissenschaftliches Zentrum Göttingen, Universität Göttingen, Germany \\ Maria Pevzner and Leopold Sulerzhitsky \\ Geological Institute, Moscow, Russia
}

Late Pleistocene-Holocene volcanism in Kamchatka results from the subduction of the Pacific Plate under the peninsula and forms three volcanic belts arranged in en echelon manner from southeast to northwest. The cross-arc extent of recent volcanism exceeds $250 \mathrm{~km}$ and is one of the widest worldwide. All the belts are dominated by mafic rocks. Eruptives with $\mathrm{SiO}_{2}>57 \%$ constitute $~ 25 \%$ of the most productive Central Kamchatka Depression belt and $\sim 30 \%$ of the Eastern volcanic front, but $<10 \%$ of the least productive Sredinny Range belt.

All the Kamchatka volcanic rocks exhibit typical arc-type signatures and are represented by basalt-rhyolite series differing in alkalis. Typical Kamchatka arc basalts display a strong increase in LILE, LREE and HFSE from the front to the back-arc. $\mathrm{La} / \mathrm{Yb}$ and $\mathrm{Nb} / \mathrm{Zr}$ increase from the arc front to the back arc while $\mathrm{B} / \mathrm{Li}$ and $\mathrm{As}, \mathrm{Sb}, \mathrm{B}, \mathrm{Cl}$ and $\mathrm{S}$ concentrations decrease. The initial mantle source below Kamchatka ranges from N-MORB-like in the volcanic front and Central Kamchatka Depression to more enriched in the back arc. Rocks from the Central Kamchatka Depression range in ${ }^{87} \mathrm{Sr} /{ }^{86} \mathrm{Sr}$ ratios from 0.70334 to 0.70366 , but have almost constant $\mathrm{Nd}$ isotopic ratios $\left({ }^{143} \mathrm{Nd} /{ }^{144} \mathrm{Nd} 0.51307-0.51312\right)$. This correlates with the highest $\mathrm{U} / \mathrm{Th}$ ratios in these rocks and suggest the highest fluid-flux in the source region.

Holocene large eruptions and eruptive histories of individual Holocene volcanoes have been studied with the help of tephrochronology and ${ }^{14} \mathrm{C}$ dating that permits analysis of time-space patterns of volcanic activity, evolution of the erupted products, and volcanic hazards.

\section{INTRODUCTION}

Models of active volcanism along subduction zones presume that lithospheric plates have been moving uniformly

\footnotetext{
${ }^{1}$ Now at Institute of Volcanology and Seismology, PetropavlovskKamchatsky, Russia

Volcanism and Subduction: The Kamchatka Region Geophysical Monograph Series 172

Copyright 2007 by the American Geophysical Union. 10.1029/172GM15
}

over thousands of years and that magma in subduction zones is generated continuously and at a constant rate. However, eruptions of magma at the surface are episodic or clustered, rather than constant or periodic in time [e.g. Cambray and Cadet, 1996; Sigurdsson, 2000; Gusev et al., 2003]. Furthermore, the volcanic belt may consist of vents, scattered out over a much wider zone and erupting more variable magmas than anticipated by a simple model of subduction-generated magma flow. In Kamchatka, subduction is responsible for most of recent volcanism [e.g. Volynets, 
1994; Churikova et al., 2001, 2007; Avdeiko et al., 2006; Portnyagin et al., 2007a, b]. However, its spatial distribution and time patterns are rather complicated. In this paper, we present data on the latest period of volcanic activity in Kamchatka, which started 50-60 ka BP [Erlich et al., 1979]. It was during this period when dominantly pyroclastic classical conic stratovolcanoes started to form, which now comprise a typical volcanic landscape of Kamchatka (Fig. 1).

The Kamchatka Peninsula overlies the northwestern margin of the Pacific plate subducting under Kamchatka at $\sim 8 \mathrm{~cm} / \mathrm{yr}$ [DeMets, 1992]. In the north, the Kamchatka subduction zone terminates at the transform fault zone of the Western Aleutians (Figs. 2A, B). Close to the northern terminus of the subduction zone, slab dip is believed to shallow from $55^{\circ}$ to $35^{\circ}$, with probable loss of a slab fragment [Levin et al., 2002; Park et al., 2002]. Plate geometry in this northwest "corner" is currently under debate [e.g. Riegel et al., 1993; Mackey et al., 1997; McElfresh et al., 2002; Bourgeois et al., 2006]. Some authors treat Kamchatka as a part of the North American plate [e.g. Park et al., 2002], while others locate it on a smaller Okhotsk block (or microplate) [e.g. Zonenshain and Savostin, 1979; Riegel et al., 1993] and add a Bering block east of it [e.g. Lander et al., 1994; Mackey et al., 1997]. Whatever the plates' evolution may have been, it is likely recorded in the time-space patterns of Kamchatka volcanism and in geo- chemical affinities of the volcanic rocks. The best example of this connection are findings of adakite-like rocks in northern Kamchatka, probably reflecting the edge of the subducting Pacific plate being warmed or ablated by mantle flow [Volynets et al., 1997b, 1999b, 2000; Peyton, 2001; Yogodzinski et al., 2001a]. Research aimed at understanding of the nature of various volcanic zones in Kamchatka and their relation to the changing tectonic environment is currently going on in many areas of Kamchatka [e.g., Avdeiko et al., 2006; Churikova et al., 2001, 2007; Duggen et al., 2007; Perepelov, 2004; Perepelov et al., 2005; Portnyagin et al., 2005, 2007a, b; Volynets et al., 2005] and hopefully will result in the understanding of this dynamic region.

\section{SPATIAL DISTRIBUTION}

Traditionally, recent Kamchatka volcanoes are assigned to two volcanic belts: Eastern volcanic belt and Sredinny Range (SR). The Eastern belt may be further subdivided into the Eastern volcanic front (EVF) and the Central Kamchatka Depression (CKD) volcanic zone (Fig. 2A). In fact, all the belts are not exactly linear and have a complicated structure (Fig. 2B). This might reflect subduction of sea mounts [e.g. Churikova et al., 2001] and peculiarities of the tectonic situation near a triple junction of lithospheric plates [e.g. Yogodzinski et al., 2001a; Park et al., 2002; Portnyagin et al.,

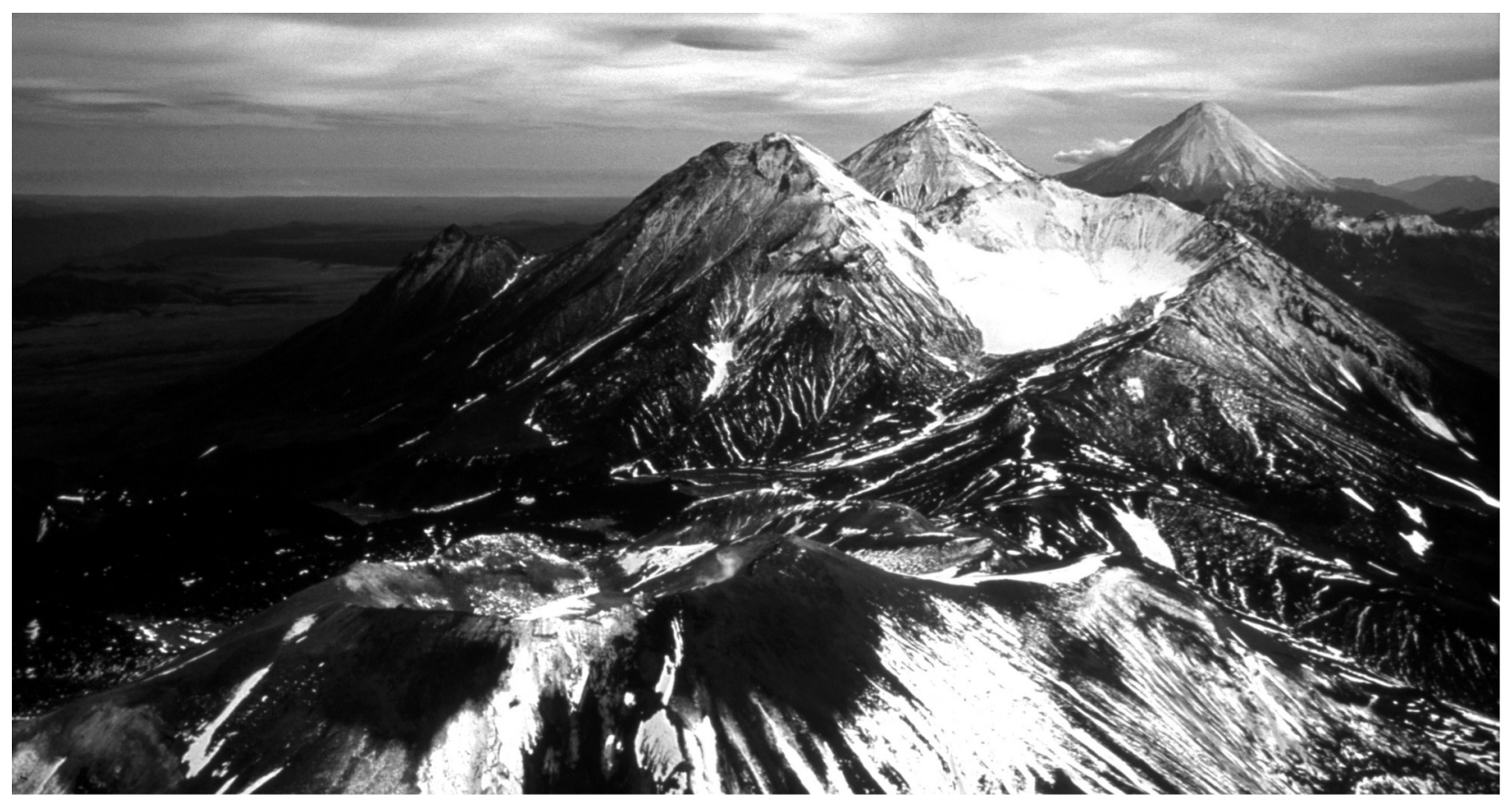

Figure 1. Eastern volcanic front, view to the south. Active Komarov volcano at the foreground, two late Pleistocene cones of Gamchen massif farther south, and Kronotsky volcano at the background. Classic cones of dominantly pyroclastic stratovolcanoes started to form only in late Pleistocene [Braitseva et al., 1974]. Photo courtesy Philippe Bourseiller. 


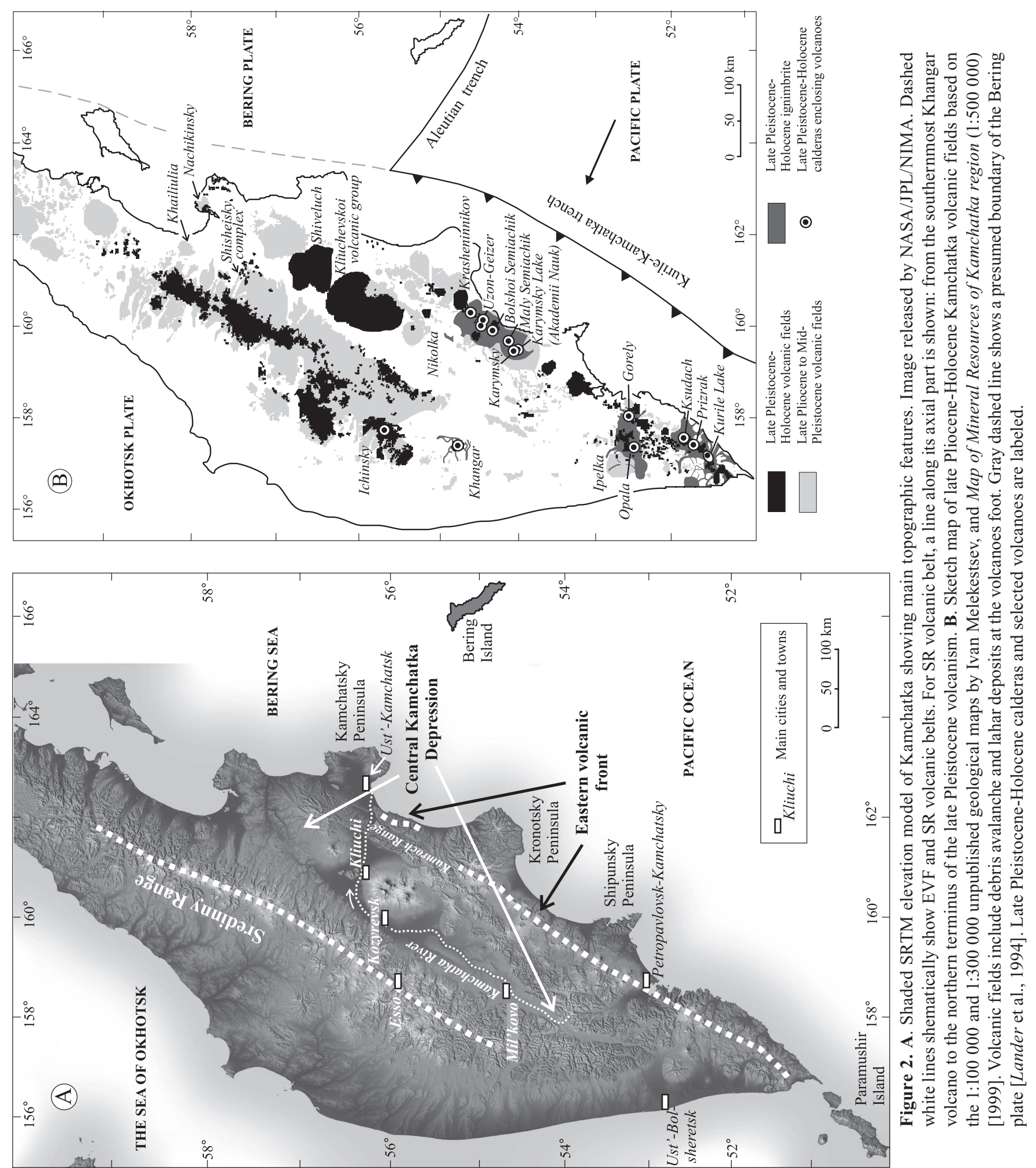


2005; 2007b]. Distribution of the late Pleistocene-Holocene volcanic vents follows in general that of the preceding late Pliocene - mid-Pleistocene volcanic fields (Fig. 2B). The latter, however, cover far larger areas and comprise extensive mafic lava plateaus and huge shield volcanoes, still preserved in the topography [Braitseva et al., 1974].

There is no evident spatial correlation between late Pleistocene-Holocene volcanic centers and major active fault systems that bound main neotectonic structures of the peninsula (Fig. 3A). The only regional fault system that may be spatially linked to volcanism is found along the axis of the EVF and is different, both geometrically and kinematically, from other, "amagmatic", fault systems. The faults comprising this system exhibit dominantly normal displacement, probably with a small left-lateral component, and form a graben-in-graben structure $\sim 130$ $\mathrm{km}$ long and 10-18 km-wide [Florensky and Trifonov, 1985; Kozhurin, 2004].

Historically active volcanoes are located only in the Eastern volcanic belt (both in the EVF and CKD) (Table 1). This is likely the reason for a widely accepted opinion that Sredinny Range volcanism either is dying [e.g. Avdeiko et al., 2002, 2006] or is already dead [e.g. Park et al., 2002]. "Historical" time in Kamchatka, however, is very short200-300 years - and tephrochronological studies and ${ }^{14} \mathrm{C}$ dating show that some Sredinny Range volcanoes have been active as recently as few hundreds of years ago [Pevzner, 2004, 2006]. Late Pleistocene-Holocene volcanic fields cover large areas in the Sredinny Range not lesser than in the eastern Kamchatka (Fig. 3A), [Ogorodov et al., 1972].

Three late Pleistocene-Holocene volcanic belts (those of EVF, CKD and SR) in plan view are arranged in en echelon manner from southeast to northwest (Fig. 2B). Within the belts, most of the eruptive centers are concentrated in 15-10 $\mathrm{km}$ wide axial areas. Best expressed is the EVF, which lies 200-250 km west of the Kurile-Kamchatka trench. It trends for $\sim 550 \mathrm{~km}$ from SW to NE, from Kambalny volcano at the south to a relatively small group of late Pleistocene cinder cones dotting the eastern slope of the Kumroch Range almost as far north as the mouth of the Kamchatka River (Fig. 2A). These cones (including Kovrizhka and Krasny (Fig. 4B)) are commonly disregarded, in which case the EVF is considered to stretch only up to the Gamchen volcanic group and then step westward to the CKD via Kizimen volcano (Fig. 3A) [e.g. Churikova et al., 2001; Park et al., 2002]. EVF per se has a more or less linear plan view with westward offshoots to Opala volcano in the south and to Bakening volcano (against Shipunsky Peninsula) (Fig. $3 \mathrm{~A})$. The volcanic front consists of rather tightly spaced stratovolcanoes only $15-30$ to $60 \mathrm{~km}$ apart from each other. Maly Semiachik and Krasheninnikov volcanoes consist of 2-3 overlapping cones stretching along the axial fault zone (Figs. 3A and 5), while Zhupanovsky, KozelskyAvachinsky-Koriaksky, Gorely and Koshelev volcanoes form prominent across-front ranges [Holocene volcanoes in Kamchatka, http://www.kscnet.ru/ivs/volcanoes/holocene]. Most of 5-18 km wide collapse calderas and associated ignimbrite fields are located in the EVF, forming chains between Kronotsky and Karymsky lakes and then from Ksudach to Kurile Lake (Fig. 2B) and (Table 2).

The next volcanic belt to the northwest is the CKD one, hosting the most vigorous volcanoes of Kamchatka (Figs. 2, 3 and 4). Most of the volcanic centers, including large volcanoes and clusters of monogenetic vents, are concentrated in a 150-km-long belt from Tolbachik lava field in the south to Shiveluch volcano in the north. A few smaller monogenetic vents are scattered over old Nikolka volcano $\sim 30$ $\mathrm{km}$ south of this zone, and near old Nachikinsky volcano $\sim 150 \mathrm{~km}$ NE of Shiveluch. Some authors trace this zone farther south via monogenetic vents at old Ipelka volcano (west of Opala) and then to a back-arc western volcanic zone of the Kurile arc (Fig. 3A) [Melekestsev et al., 1974; Laverov, 2005]. A number of monogenetic vents scattered on the eastern slope of the Sredinny Range in the Elovka River basin (sometimes called "Shisheisky Complex") $60-80 \mathrm{~km} \mathrm{NNW}$ of Shiveluch (Fig. 2B) likely also should be attributed to the CKD rather than to SR volcanic zone based on their geochemical features [Portnyagin et al., 2007b]. Geographically, however, many of those belong to Sredinny Range, so in (Table 1) we enlist the Holocene vents from this group (Bliznetsy, Kinenin and Shisheika, (Fig. 4B) under "Sredinny Range". No ignimbrite-related calderas are known to date in CKD; 3-5 km wide summit calderas on Plosky Dalny (Ushkovsky) and Plosky Tolbachik volcanoes resulted from the collapse due to lava drainage [Melekestsev et al., 1974].

The next late Pleistocene-Holocene volcanic belt to the northwest, that of SR, starts from the isolated Khangar intracaldera volcano in the south, then widens for $100 \mathrm{~km}$ farther north and finally merges into a single narrow belt following the axis of the Sredinny Range (Figs. 2A and B). Unlike EVF and CKD with their conic stratovolcanoes, SR hosts mostly lava fields and a few shield-like volcanoes (with the exception of Khangar and Ichinsky intra-caldera edifices).

The widest possible cross-arc extent of recent volcanism (and one of the widest worldwide) forms a $\sim 250 \times 250 \mathrm{~km}^{2}$ zone stretching from the Pacific coast inland along the projection of the Aleutian trend (Fig. 3B). This unusually wide range of recent volcanism coincides with slab shallowing [Gorbatov et al., 1997] and likely results from the subduction of the Emperor Seamount chain [Churikova et al., 2001]. 
Table 1. Kamchatka volcanoes active in Holocene

\begin{tabular}{|c|c|c|c|c|}
\hline Name & $\begin{array}{l}\text { Locatio } \\
\text { an activ } \\
\text { crater, } \\
\text { Lat. N } \\
\text { Long.E }\end{array}$ & Description & $\begin{array}{l}\text { Last dated } \\
\text { eruption, } \mathrm{AD} \text { or } \\
{ }^{14} \mathrm{C} \text { yr BP }\end{array}$ & Dominating Holocene rocks \\
\hline
\end{tabular}

\section{Eastern volcanic front}

\section{Central Kamchatka Depression}

Shiveluch

Plosky Dalny (Ushkovsky)

Kliuchevskoi

Bezymianny

Plosky Tolbachik

Tolbachik lava field

(south and northeast of Plosky Tolbachik)

Kizimen

\section{Eastern volcanic front}

Vysoky

Komarov

Gamchen (Baranii Cone)

Kronotsky

Cinder cones between Kronotsky Lake and Krasheninnikov caldera

Krasheninnikov

Cinder cones south of Krasheninnikov caldera $56^{\circ} 38^{\prime}$ $161^{\circ} 19^{\prime}$

(Young Shiveluch)

$56^{\circ} 04$ $160^{\circ} 28^{\prime}$

$56^{\circ} 03^{\prime}$ $160^{\circ} 39^{\prime}$

$55^{\circ} 58^{\prime}$ $160^{\circ} 36^{\prime}$

$55^{\circ} 49^{\prime}$ $160^{\circ} 23^{\prime}$

$55^{\circ} 04^{\prime}$ $160^{\circ} 46^{\prime}$

$55^{\circ} 02^{\prime}$ $160^{\circ} 44^{\prime}$

$54^{\circ} 58^{\prime}$ $160^{\circ} 43^{\prime}$

$54^{\circ} 45^{\prime}$ $160^{\circ} 32^{\prime}$

$54^{\circ} 38^{\prime}$ $161^{\circ} 19^{\prime}$ (Northern Cone)
Late Pleistocene stratovolcano with a collapse crater hosting Holocene Young Shiveluch eruptive center

Late Pleistocene stratovolcano with two summit calderas and Holocene flank vents (e.g., Lavovy Shish)

Holocene stratovolcano with numerous flank vents

Holocene stratovolcano with growing lava dome

Late Pleistocene stratovolcano with two summit calderas, active in Holocene

Numerous Holocene cinder cones and associated lava field

Holocene volcano made of lava domes and flows

Holocene stratovolcano

Holocene stratovolcano, likely successor to Vysoky

Holocene dominantly pyroclastic volcano with flank lava domes

Late Pleistocene stratovolcano with Holocene flank cinder cones

Numerous cinder cones with lava flows, maar

Two coalesced Holocene stratovolcanoes with flank vents inside a late Pleistocene caldera

A number of cinder cones
AD 2007

Medium-K, high-Mg and $\mathrm{Cr}$ basaltic andesite -andesite series

Medium- and high-K basalt - basaltic andesite

AD $2007 \quad$ Medium-K basaltbasaltic andesite

AD $2007 \quad$ Medium-K basaltic andesite-andesite series

High-K basalt

AD 1975-76

High-K, high-Al basalt and medium-K, high $\mathrm{Mg}$ basalt

AD 1927-28

Medium-K basaltic andesite - dacite series

Transitional from lowto medium-K basaltic andesite-andesite series

AD 1923

$\sim 3400$

(Zametny

Cone)

400-500

3200-3300 (Duga Cone)

Transitional from low- to medium-K calc-alkaline andesite

Low-K basaltic andesiteandesite

Low-K basalt-basaltic andesite; andesite?

Medium-K tholeiitic basaltic andesite

Medium-K tholeiitic basalt-dacite series

Medium-K tholeiitic basaltic andesite-andesite 
Table 1. Cont.

\begin{tabular}{|c|c|c|c|c|}
\hline Name & $\begin{array}{l}\text { Location of } \\
\text { an active } \\
\text { crater, } \\
\text { Lat. N } \\
\text { Long.E }\end{array}$ & Description & $\begin{array}{l}\text { Last dated } \\
\text { eruption, } \mathrm{AD} \text { or } \\
{ }^{14} \mathrm{C} \text { yr BP }\end{array}$ & Dominating Holocene rocks \\
\hline Kikhpinych & $\begin{array}{l}54^{\circ} 29^{\prime} \\
160^{\circ} 16^{\prime} \\
\text { (Savich } \\
\text { Cone) }\end{array}$ & $\begin{array}{l}\text { Two coalesced Holocene } \\
\text { stratovolcanoes and a lava dome }\end{array}$ & $\sim 500$ & $\begin{array}{l}\text { Low-K basalt-basaltic } \\
\text { andesite }\end{array}$ \\
\hline Taunshits & $\begin{array}{l}54^{\circ} 32^{\prime} \\
159^{\circ} 48^{\prime} \\
\text { (young } \\
\text { dome) }\end{array}$ & $\begin{array}{l}\text { Late Pleistocene stratovolcano with } \\
\text { Holocene collapse crater and lava } \\
\text { dome }\end{array}$ & $\sim 2400$ & $\begin{array}{l}\text { Medium-K calc-alkaline } \\
\text { basaltic andesite-andesite }\end{array}$ \\
\hline $\begin{array}{l}\text { Monogenetic craters inside Uzon } \\
\text { caldera }\end{array}$ & & $\begin{array}{l}\text { Dalnee Lake tuff ring and a number } \\
\text { of maars }\end{array}$ & $\begin{array}{l}\text { Small phreatic } \\
\text { eruption in AD } \\
1989 \text {; Dalnee } \\
\text { Lake } 7600-7700\end{array}$ & $\begin{array}{l}\text { Dalnee Lake -medium- } \\
\text { K tholeiitic basaltic } \\
\text { andesite }\end{array}$ \\
\hline $\begin{array}{l}\text { Monogenetic lava domes in Bolshoi } \\
\text { Semiachik caldera }\end{array}$ & & Lava domes, some with lava flows & $\begin{array}{l}\text { Ezh and Korona } \\
\text { domes } \sim 5600\end{array}$ & Low-K andesite \\
\hline Maly Semiachik & $\begin{array}{l}54^{\circ} 07^{\prime} \\
159^{\circ} 39^{\prime} \\
\text { (Troitsky } \\
\text { Crater) }\end{array}$ & $\begin{array}{l}\text { Three coalesced stratovolcanoes } \\
\text { inside a late Pleistocene caldera }\end{array}$ & AD 1952 & $\begin{array}{l}\text { Medium-K tholeiitic } \\
\text { basalt-andesite series and } \\
\text { low-K basalt (?) }\end{array}$ \\
\hline Karymsky & $\begin{array}{r}54^{\circ} 03^{\prime} \\
159^{\circ} 27^{\prime}\end{array}$ & $\begin{array}{l}\text { Holocene caldera enclosing a } \\
\text { stratovolcano }\end{array}$ & AD 2007 & $\begin{array}{l}\text { Medium-K calc-alkaline } \\
\text { basaltic-andesite-rhyolite } \\
\text { series }\end{array}$ \\
\hline $\begin{array}{l}\text { Tuff rings near the northern shore of } \\
\text { the Karymsky Lake }\end{array}$ & & At least two Holocene tuff rings & AD 1996 & $\begin{array}{l}\text { Medium-K calc-alkaline } \\
\text { basaltic andesite }\end{array}$ \\
\hline $\begin{array}{l}\text { Cinder cones in Levaia Avacha } \\
\text { River valley (east of Bakening): } \\
\text { Zavaritsky, Veer, etc. }\end{array}$ & & $\begin{array}{l}\text { Scattered cinder cones with lava } \\
\text { flows, maar }\end{array}$ & $\begin{array}{l}1600-1700 \\
\text { (Veer Cone) }\end{array}$ & $\begin{array}{l}\text { Medium-K basalt- } \\
\text { basaltic andesite }\end{array}$ \\
\hline Novo-Bakening & $\begin{array}{r}53^{\circ} 57^{\prime} \\
158^{\circ} 06^{\prime}\end{array}$ & $\begin{array}{l}\text { Large monogenetic center with lava } \\
\text { flows }\end{array}$ & Early Holocene & $\begin{array}{l}\text { Medium-K andesite - } \\
\text { dacite }\end{array}$ \\
\hline Bakening & $\begin{array}{r}53^{\circ} 55^{\prime} \\
158^{\circ} 05^{\prime}\end{array}$ & Late Pleistocene stratovolcano & Early Holocene & Medium-K andesite \\
\hline Cinder cones south of Bakening & & $\begin{array}{l}\text { Scattered cinder cones with lava } \\
\text { flows, maars }\end{array}$ & $\begin{array}{l}\sim 600 \\
\text { (Kostakan) }\end{array}$ & $\begin{array}{l}\text { Medium- } \mathrm{K} \text { basalt- } \\
\text { basaltic andesite }\end{array}$ \\
\hline Zhupanovsky & $\begin{array}{r}53^{\circ} 35^{\prime} \\
159^{\circ} 08^{\prime}\end{array}$ & $\begin{array}{l}\text { Late Pleistocene-Holocene volcanic } \\
\text { range made of stratovolcanoes and } \\
\text { lava domes }\end{array}$ & AD 1956-57 & $\begin{array}{l}\text { Transitional from low- } \\
\text { to medium-K basalt- } \\
\text { andesite series }\end{array}$ \\
\hline $\begin{array}{l}\text { Lava cones and flows west of } \\
\text { Zhupanovsky }\end{array}$ & & $\begin{array}{l}\text { Lava cones with extensive and thick } \\
\text { lava flows }\end{array}$ & $\sim 1600$ & Medium-K andesite \\
\hline Koriaksky & $\begin{array}{r}53^{\circ} 19^{\prime} \\
158^{\circ} 43^{\prime}\end{array}$ & $\begin{array}{l}\text { Late Pleistocene-Holocene } \\
\text { stratovolcano }\end{array}$ & AD 1956-57 & $\begin{array}{l}\text { Medium-K basalt- } \\
\text { andesite series }\end{array}$ \\
\hline Avachinsky & $\begin{array}{r}53^{\circ} 15^{\prime} \\
158^{\circ} 50^{\prime}\end{array}$ & $\begin{array}{l}\text { Late Pleistocene stratovolcano with } \\
\text { a collapse crater hosting Young } \\
\text { Cone Holocene stratovolcano }\end{array}$ & AD 2001 & $\begin{array}{l}\text { Low-K basaltic andesite- } \\
\text { andesite series }\end{array}$ \\
\hline Kozelsky & $\begin{aligned} 53^{\circ} 14^{\prime} \\
158^{\circ} 53^{\prime}\end{aligned}$ & $\begin{array}{l}\text { Late Pleistocene stratovolcano } \\
\text { with a collapse crater }\end{array}$ & Early Holocene & $\begin{array}{l}\text { Low-K basaltic andesite- } \\
\text { andesite series }\end{array}$ \\
\hline
\end{tabular}


Table 1. Cont.

\begin{tabular}{|c|c|c|c|c|}
\hline Name & $\begin{array}{l}\text { Location of } \\
\text { an active } \\
\text { crater, } \\
\text { Lat. N } \\
\text { Long.E }\end{array}$ & Description & $\begin{array}{l}\text { Last dated } \\
\text { eruption, } \mathrm{AD} \text { or } \\
{ }^{14} \mathrm{C} \text { yr BP }\end{array}$ & Dominating Holocene rocks \\
\hline $\begin{array}{l}\text { Cinder cones south of Nachikinsky } \\
\text { Lake (north of Tolmachev lava field) }\end{array}$ & & A number of cinder cones & $?$ & $?$ \\
\hline Cinder cones north of Viliuchinsky & & $\begin{array}{l}\text { Scattered cinder cones with lava } \\
\text { flows }\end{array}$ & $\begin{array}{l}\text { Middle } \\
\text { Holocene }\end{array}$ & $\begin{array}{l}\text { Medium-K basaltic } \\
\text { andesite }\end{array}$ \\
\hline Viliuchinsky & $\begin{array}{r}52^{\circ} 42^{\prime} \\
158^{\circ} 17^{\prime}\end{array}$ & Late Pleistocene stratovolcano & Early Holocene & $\begin{array}{l}\text { Medium-K basaltic } \\
\text { andesite }\end{array}$ \\
\hline Tolmachev lava field & & $\begin{array}{l}\text { Late Pleistocene-Holocene cinder } \\
\text { cones and associated lava field }\end{array}$ & $1600-1700$ & $\begin{array}{l}\text { Medium-K basaltic } \\
\text { andesite }\end{array}$ \\
\hline $\begin{array}{l}\text { Chasha Crater } \\
\text { (Tolmachev lava field) }\end{array}$ & $\begin{array}{r}52^{\circ} 38^{\prime} \\
157^{\circ} 33^{\prime}\end{array}$ & A large monogenetic crater & $\sim 4600$ & $\begin{array}{l}\text { Transitional from } \\
\text { medium to high-K } \\
\text { rhyolite }\end{array}$ \\
\hline Opala & $\begin{array}{r}52^{\circ} 33^{\prime} \\
157^{\circ} 20^{\prime}\end{array}$ & $\begin{array}{l}\text { Late Pleistocene-Holocene volcano } \\
\text { on the rim of the late Pleistocene } \\
\text { caldera with flank vents including } \\
\text { a large crater Baranii Amphitheater } \\
\text { with lava domes inside }\end{array}$ & AD 1776 & $\begin{array}{l}\text { Transitional from } \\
\text { medium to high-K } \\
\text { basaltic andesite-rhyolite } \\
\text { series }\end{array}$ \\
\hline $\begin{array}{l}\text { Cinder cones and maar SSW of } \\
\text { Opala caldera }\end{array}$ & & Two cinder cones and maar & $\begin{array}{l}\text { Early } \\
\text { Holocene? }\end{array}$ & $?$ \\
\hline Gorely & $\begin{array}{l}52^{\circ} 33^{\prime} \\
158^{\circ} 02^{\prime} \\
\text { (Active } \\
\text { Crater) }\end{array}$ & $\begin{array}{l}\text { Late Pleistocene-Holocene volcanic } \\
\text { ridge inside the late Pleistocene } \\
\text { caldera }\end{array}$ & AD 1986 & $\begin{array}{l}\text { Medium- and high-K } \\
\text { basaltic andesite - } \\
\text { andesite }\end{array}$ \\
\hline Mutnovsky & $\begin{array}{l}52^{\circ} 28^{\prime} \\
158^{\circ} 10^{\prime} \\
\text { (Active } \\
\text { Crater) }\end{array}$ & $\begin{array}{l}\text { Late Pleistocene volcanic massif } \\
\text { with a Holocene stratovolcano }\end{array}$ & AD 2000 & $\begin{array}{l}\text { Low- and medium-K } \\
\text { basalt-basaltic andesite }\end{array}$ \\
\hline Asacha & $\begin{array}{r}52^{\circ} 21^{\prime} \\
157^{\circ} 50^{\prime}\end{array}$ & $\begin{array}{l}\text { Large volcanic center with } \\
\text { Holocene cinder cones at the } \\
\text { western flank }\end{array}$ & $?$ & $?$ \\
\hline $\begin{array}{l}\text { Khodutkinsky Crater } \\
\text { (NW of Khodutka) }\end{array}$ & $\begin{array}{r}52^{\circ} 05^{\prime} \\
157^{\circ} 38^{\prime}\end{array}$ & $\begin{array}{l}\text { Large monogenetic crater with a } \\
\text { lava dome }\end{array}$ & $\sim 2500$ & Medium-K rhyolite \\
\hline Khodutka & $\begin{array}{r}52^{\circ} 04^{\prime} \\
157^{\circ} 43^{\prime}\end{array}$ & $\begin{array}{l}\text { Late Pleistocene-Holocene } \\
\text { stratovolcano }\end{array}$ & 2000? & $\begin{array}{l}\text { Low-K basalt-andesite } \\
\text { series }\end{array}$ \\
\hline Cinder cones W-SW of Khodutka & & Cinder cones with lava flows & Holocene & $?$ \\
\hline Ksudach & $\begin{array}{l}51^{\circ} 49^{\prime} \\
157^{\circ} 32^{\prime} \\
\text { (Stübel } \\
\text { Cone) }\end{array}$ & $\begin{array}{l}\text { Large caldera complex with } 3 \\
\text { Holocene calderas and Stübel } \\
\text { stratovolcano }\end{array}$ & AD 1907 & $\begin{array}{l}\text { Low-K basaltic andesite- } \\
\text { rhyolite series }\end{array}$ \\
\hline Zheltovsky & $\begin{array}{r}51^{\circ} 35^{\prime} \\
157^{\circ} 20^{\prime}\end{array}$ & $\begin{array}{l}\text { Late Pleistocene stratovolcano with } \\
\text { Holocene lava domes }\end{array}$ & AD 1923 & $\begin{array}{l}\text { Low-K basalt-andesite } \\
\text { series }\end{array}$ \\
\hline Iliinsky & $\begin{aligned} 51^{\circ} 30^{\prime} \\
157^{\circ} 12^{\prime}\end{aligned}$ & $\begin{array}{l}\text { Holocene stratovolcano with flank } \\
\text { vents inside a Holocene collapse } \\
\text { crater on the pre-Iliinsky volcano }\end{array}$ & AD 1901 & $\begin{array}{l}\text { Transitional from low- } \\
\text { to medium-K tholeiitic } \\
\text { basalt to dacite series }\end{array}$ \\
\hline
\end{tabular}


Table 1. Cont.

\begin{tabular}{|c|c|c|c|c|}
\hline Name & $\begin{array}{l}\text { Location of } \\
\text { an active } \\
\text { crater, } \\
\text { Lat. N } \\
\text { Long.E }\end{array}$ & Description & $\begin{array}{l}\text { Last dated } \\
\text { eruption, AD or } \\
{ }^{14} \mathrm{C} \text { yr BP }\end{array}$ & Dominating Holocene rocks \\
\hline Kurile Lake caldera & & $\begin{array}{l}\text { Holocene caldera enclosing lava } \\
\text { domes }\end{array}$ & $\sim 7600$ & $\begin{array}{l}\text { Transitional from low- } \\
\text { to medium-K basaltic } \\
\text { andesite to rhyolite series }\end{array}$ \\
\hline $\begin{array}{l}\text { Ukho and Gorely cinder cones } \\
\text { (NW of Koshelev) }\end{array}$ & & Cinder cones with lava flows & $\sim 6000$ & Medium-K basalt \\
\hline Dikii Greben' & $\begin{aligned} 51^{\circ} 27^{\prime} \\
156^{\circ} 59^{\prime}\end{aligned}$ & Holocene extrusive massif & $\sim 1600$ & $\begin{array}{l}\text { Medium-K dacite - } \\
\text { rhyolite }\end{array}$ \\
\hline Koshelev & $\begin{array}{l}51^{\circ} 21^{\prime} \\
156^{\circ} 45^{\prime} \\
\text { (Eastern } \\
\text { Cone) }\end{array}$ & $\begin{array}{l}\text { Pleistocene volcanic ridge with } \\
\text { Holocene cinder cone and lava } \\
\text { flows }\end{array}$ & AD $1741 ?$ & $\begin{array}{l}\text { Medium-K basaltic } \\
\text { andesite to dacite series }\end{array}$ \\
\hline Kambalny & $\begin{array}{r}51^{\circ} 18^{\prime} \\
156^{\circ} 53^{\prime}\end{array}$ & Holocene stratovolcano & AD 1767 & $\begin{array}{l}\text { Low-K basalt-basaltic } \\
\text { andesite }\end{array}$ \\
\hline \multicolumn{5}{|c|}{ Sredinny Range } \\
\hline Tobeltsen & $\begin{array}{r}58^{\circ} 15^{\prime} \\
160^{\circ} 44^{\prime}\end{array}$ & Cinder cone with lava flows & $\sim 3500$ & Medium-K basalt \\
\hline X Cone & $\begin{aligned} 58^{\circ} 10^{\prime} \\
160^{\circ} 48^{\prime}\end{aligned}$ & Lava cone with a lava flow & $\sim 4000$ & Medium-K basalt \\
\hline Spokoiny (Kutina ${ }^{1}$ ) & $\begin{array}{r}58^{\circ} 08^{\prime} \\
160^{\circ} 49^{\prime}\end{array}$ & $\begin{array}{l}\text { Late Pleistocene-Holocene } \\
\text { stratovolcano }\end{array}$ & $\sim 5400$ & $\begin{array}{l}\text { Transitional from } \\
\text { medium to high-K } \\
\text { dacite-rhyolite }\end{array}$ \\
\hline Nylgimelkin (Atlasov' ${ }^{1}$ ) & $\begin{array}{r}57^{\circ} 58^{\prime} \\
160^{\circ} 39^{\prime}\end{array}$ & $\begin{array}{l}\text { Small shield-like volcano topped } \\
\text { with two cinder cones } \\
\text { (likely one eruption) }\end{array}$ & $\sim 5500$ & Medium-K basalt \\
\hline Ozernovsky & $\begin{array}{r}57^{\circ} 35^{\prime} \\
160^{\circ} 38^{\prime}\end{array}$ & Cinder cone with lava field & $9000-10,000$ & Medium-K basalt \\
\hline Titila & $\begin{array}{r}57^{\circ} 24^{\prime} \\
160^{\circ} 07^{\prime}\end{array}$ & Shield-like volcano & $2500-3000$ & $\begin{array}{l}\text { Transitional from } \\
\text { medium to high-K basalt }\end{array}$ \\
\hline Sedanka lava field & & $\begin{array}{l}\text { Cinder cones and associated lava } \\
\text { flows }\end{array}$ & $2500-3000$ & $\begin{array}{l}\text { Transitional from } \\
\text { medium to high-K basalt }\end{array}$ \\
\hline Kinenin Maar & $\begin{aligned} 57^{\circ} 21^{\prime} \\
160^{\circ} 58^{\prime}\end{aligned}$ & Maar with some juvenile tephra & $\sim 1100$ & $\begin{array}{l}\text { Medium-K basaltic } \\
\text { andesite }\end{array}$ \\
\hline Bliznetsy (“Twins") & $\begin{array}{r}57^{\circ} 21^{\prime} \\
161^{\circ} 22^{\prime}\end{array}$ & Lava domes and flows & $\sim 3000$ & Medium-K andesite \\
\hline Gorny Institute & $\begin{array}{r}57^{\circ} 20^{\prime} \\
160^{\circ} 11^{\prime}\end{array}$ & $\begin{array}{l}\text { Late Pleistocene-Holocene } \\
\text { stratovolcano }\end{array}$ & $<700$ & $\begin{array}{l}\text { Transitional from } \\
\text { medium to high-K } \\
\text { basaltic andesite-dacite }\end{array}$ \\
\hline Shisheika & $\begin{array}{r}57^{\circ} 09^{\prime} \\
161^{\circ} 05^{\prime}\end{array}$ & Lava dome and flow & 4200 & $\begin{array}{l}\text { Medium-K andesite- } \\
\text { dacite }\end{array}$ \\
\hline Alney & $\begin{array}{r}56^{\circ} 41^{\prime} \\
159^{\circ} 38^{\prime}\end{array}$ & $\begin{array}{l}\text { Pleistocene volcanic massif with a } \\
\text { Holocene eruptive center }\end{array}$ & $<350$ & Medium-K andesite \\
\hline
\end{tabular}


Table 1. Cont.

\begin{tabular}{|c|c|c|c|c|}
\hline Name & $\begin{array}{l}\text { Location of } \\
\text { an active } \\
\text { crater, } \\
\text { Lat. N } \\
\text { Long.E }\end{array}$ & Description & $\begin{array}{l}\text { Last dated } \\
\text { eruption, AD or } \\
{ }^{14} \mathrm{C} \text { yr BP }\end{array}$ & Dominating Holocene rocks \\
\hline $\begin{array}{l}\text { Kireunsky } \\
\text { (east of Alney) }\end{array}$ & $\begin{array}{r}56^{\circ} 41^{\prime} \\
159^{\circ} 44^{\prime}\end{array}$ & Cinder cone and lava flow & $\sim 2600$ & Medium-K andesite \\
\hline $\begin{array}{l}\text { Lava flow in Levaia Belaia River } \\
\text { (east of Alney) }\end{array}$ & $\begin{array}{r}56^{\circ} 38^{\prime} \\
159^{\circ} 43^{\prime}\end{array}$ & Cinder cone and lava flow & $\sim 2600$ & $\begin{array}{l}\text { Medium-K basaltic } \\
\text { andesite-andesite }\end{array}$ \\
\hline Kekuk Crater & $\begin{array}{r}56^{\circ} 34^{\prime} \\
158^{\circ} 02^{\prime}\end{array}$ & Tuff ring? & $7200-7300$ & Medium-K dacite \\
\hline Ichinsky & $\begin{array}{r}55^{\circ} 41^{\prime} \\
157^{\circ} 44^{\prime}\end{array}$ & $\begin{array}{l}\text { Late Pleistocene-Holocene } \\
\text { stratovolcano }\end{array}$ & AD 740 & $\begin{array}{l}\text { Transitional from } \\
\text { medium to high-K } \\
\text { andesite-dacite }\end{array}$ \\
\hline North Cherpuk & $\begin{array}{r}55^{\circ} 36^{\prime} \\
157^{\circ} 38^{\prime}\end{array}$ & Cinder cone and lava flow & $\sim 6500$ & $\begin{array}{l}\text { Medium-K basaltic } \\
\text { andesite-andesite }\end{array}$ \\
\hline South Cherpuk & $\begin{array}{r}55^{\circ} 33^{\prime} \\
157^{\circ} 28^{\prime}\end{array}$ & Cinder cones and lava field & $\sim 6500$ & $\begin{array}{l}\text { Medium-K basalt- } \\
\text { basaltic andesite }\end{array}$ \\
\hline Khangar & $\begin{array}{r}54^{\circ} 45^{\prime} \\
157^{\circ} 23^{\prime}\end{array}$ & $\begin{array}{l}\text { Late Pleistocene-Holocene } \\
\text { stratovolcano inside a late } \\
\text { Pleistocene caldera }\end{array}$ & $\sim 400$ & $\begin{array}{l}\text { Medium-K dacite- } \\
\text { rhyodacite }\end{array}$ \\
\hline
\end{tabular}

${ }^{1}$ Volcano names as in Ogorodov et al., 1972. Other names in parentheses in column 1 are other names used for this volcano in the literature. Volcano names in parentheses in column 2 indicate a summit in the volcanic massif whose coordinates are provided. Classification of the Holocene erupted products is based on $\mathrm{SiO}_{2}-\mathrm{K}_{2} \mathrm{O}$ classification by LeMaitre [1989]. The rock series, which are close to the classification lines or cross it, but form individual trends, are marked as transitional. Volcano data from the following sources: Central Kamchatka Depression and Eastern volcanic front [Bindeman and Bailey, 1994; Braitseva and Melekestsev, 1990; Braitseva et al., 1991, 1998; Churikova et al., 2001; Dirksen et al., 2002; Dorendorf et al., 2000b; Fedotov and Masurenkov, 1991; Melekestsev et al., 1992, 1995, 1996a, 2003b; Ozerov, 2000; Ponomareva, 1990; Ponomareva et al., 2004, 2006b; Selyangin and Ponomareva, 1999; Vlodavets, 1957; Volynets et al., 1989, 1999a]; Sredinny Range [Bazanova and Pevzner, 2001; Churikova et al., 2001; Dirksen et al., 2003; Pevzner, 2004, 2006; Pevzner et al., 2000; Volynets, 2006]. Question mark indicates that the data are lacking.

\section{AGE ESTIMATES}

Very few radiometric age determinations exist for late Pliocene - mid-Pleistocene volcanic rocks, underlying the late Pleistocene - Holocene volcanoes. A few ${ }^{40} \mathrm{Ar} /{ }^{39} \mathrm{Ar}$ determinations on lava plateaus in different parts of Kamchatka demonstrate that they span from 6 to $1 \mathrm{Ma}$ [Volynets et al., 2006]. K/Ar dates obtained on various volcanic rocks in the area from Bakening to Mutnovsky volcanoes cover 0.5 to $5 \mathrm{Ma}$ range, with two groups of welded tuffs dated at around 1.5 and $4 \mathrm{Ma}$ [Sheimovich and Karpenko, 1997; Sheimovich and Golovin, 2003]. Lava plateaus underlying Kliuchevskoi volcanic group were dated at 260-270 ka $\left[{ }^{40} \mathrm{Ar} /{ }^{39} \mathrm{Ar}\right.$, Calkins, 2004]. Mid-Pleistocene age was also attributed to the oldest preserved stratovolcanoes (e.g. Gorny Zub, the oldest stratovolcano within the Kliuchevskoi volcanic group) based on their relationship with glacial deposits [Melekestsev et al., 1971; Braitseva et al., 1995].
In late Pleistocene, both volcanic and non-volcanic mountains of Kamchatka hosted extensive alpine glaciers, which deposited moraines at the surrounding lowlands. Glacial deposits identified on the air- and space images, indicate two stages of the late Pleistocene glaciation with maxima assigned to 79-65 and 24-18 ka BP based on North America analogues (Early and Late Wisconsinian) [Braitseva et al., 1995]. Recently obtained ${ }^{14} \mathrm{C}$ ages related to the last glacial maximum (LGM) deposits yield $\sim 21 \mathrm{ka} \mathrm{BP}$ and fit well into the latter interval [Braitseva et al., 2005].

Since very few radiometric ages are available for the late Pleistocene volcanoes, age estimates for them are based mostly on their morphology and on the stratigraphic relationship of their products with the LGM deposits. Volcanoes, which started to form $\sim 50-60 \mathrm{ka} \mathrm{BP}$, between the two glacial maxima, are only moderately reshaped by erosion and surrounded by moraines. Preliminary data indicates that this period of volcanic activity was preceded by rather a long repose [Melekestsev et al., 1974; Calkins, 2004], however, this needs to be confirmed by further 


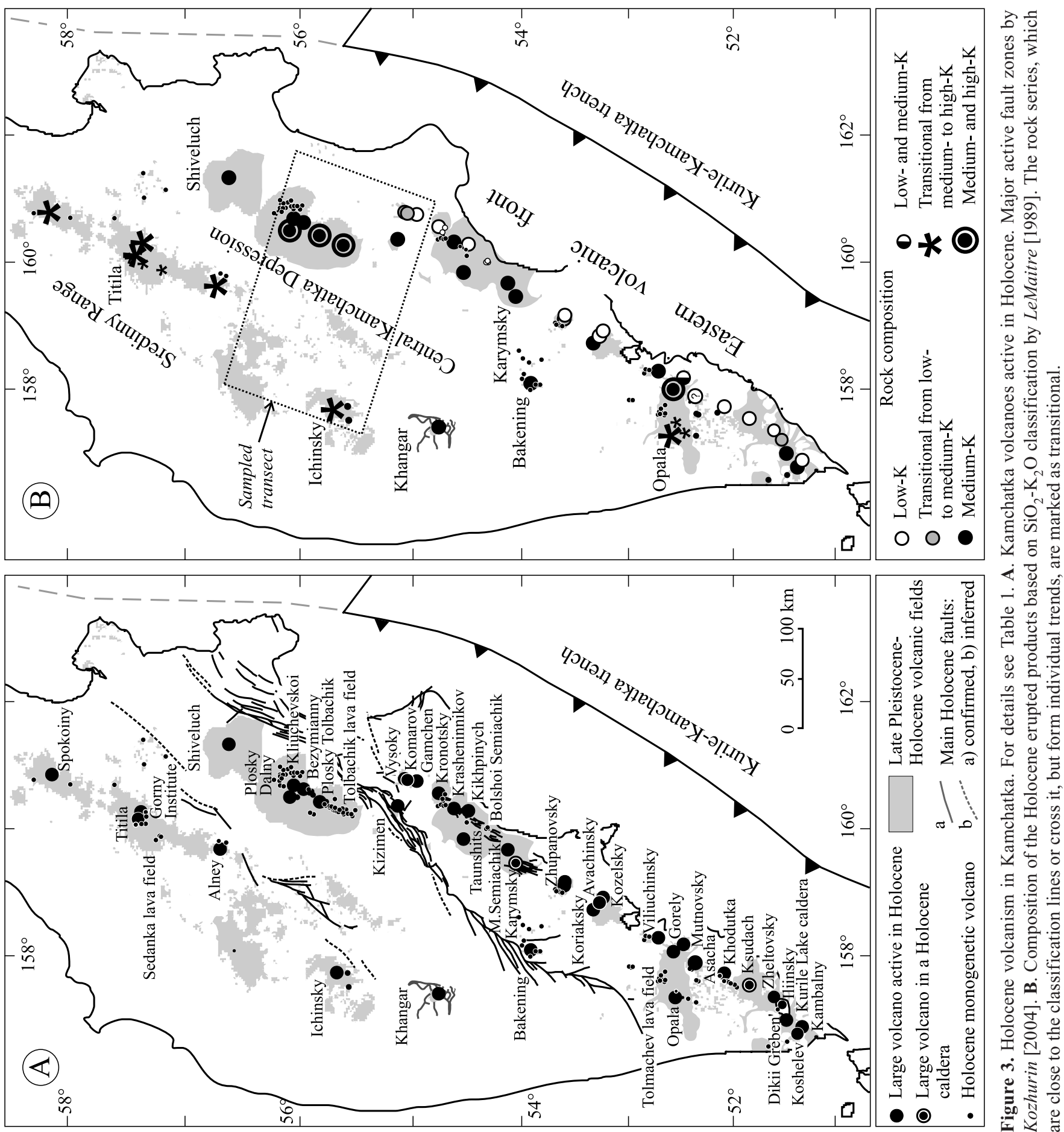


Table 2. Late Pleistocene and Holocene calderas associated with ignimbrites

\begin{tabular}{|c|c|c|c|}
\hline Caldera Name & Age (Method) & $\begin{array}{c}\text { Caldera } \\
\text { dimension } \\
(\mathrm{km})\end{array}$ & References \\
\hline Ichinsky III & Late Pleistocene (Stratigraphy) & $5 \times 3$ & Erlich, 1986; Volynets et al., 1991 \\
\hline Khangar II & $38-40 \mathrm{ka}\left({ }^{14} \mathrm{C}\right)$ & 8 & Braitseva et al., 1995, 2005 \\
\hline Krasheninnikov & $35-38 \mathrm{ka}\left({ }^{14} \mathrm{C}\right)$ & $12 \times 10$ & Florensky, 1984; Erlich, 1986 \\
\hline $\begin{array}{l}\text { Uzon-Geizerny } \\
\text { twinned caldera }\end{array}$ & $39 \mathrm{ka}\left({ }^{14} \mathrm{C}\right)$ & $18 \times 9$ & Florensky, 1984; Erlich, 1986; Leonov and Grib, 2004 \\
\hline Bolshoi Semiachik II & Late Pleistocene (Stratigraphy) & 10 & Erlich, 1986; Leonov and Grib, 2004 \\
\hline Maly Semiachik & $\sim 20 \mathrm{ka}$ (Stratigraphy) & 7 & $\begin{array}{l}\text { Selyangin et al., 1979; Erlich, 1986; Leonov and Grib, } \\
2004\end{array}$ \\
\hline Karymsky & $7.9 \mathrm{ka}\left({ }^{14} \mathrm{C}\right)$ & 5 & Braitseva et al., 1995; Erlich, 1986 \\
\hline $\begin{array}{l}\text { Akademii Nauk } \\
\text { (Karymsky Lake) }\end{array}$ & $28-48$ ka (Fission-track) & 5 & $\begin{array}{l}\text { Ananiev et al., 1980; Erlich, 1986; Leonov and Grib, } \\
2004\end{array}$ \\
\hline Gorely II & $33-34 \mathrm{ka}\left({ }^{14} \mathrm{C}\right)$ & $12 \times 9$ & Erlich, 1986; Braitseva et al., 1995 \\
\hline Opala & $39-40 \mathrm{ka}\left({ }^{14} \mathrm{C}\right)$ & 15 & Erlich, 1986; Braitseva et al., 1995 \\
\hline Ksudach I & Late Pleistocene (Morphology) & 9 & Erlich, 1986; Melekestsev et al., 1996b \\
\hline Ksudach II & Late Pleistocene (Morphology) & 8 & Melekestsev et al., 1996b \\
\hline Ksudach III & $8.8 \mathrm{ka}\left({ }^{14} \mathrm{C}\right)$ & $?$ & $\begin{array}{l}\text { Braitseva et al., 1995; Melekestsev et al., 1996b; } \\
\text { Volynets et al., 1999a }\end{array}$ \\
\hline Ksudach IV & $6 \mathrm{ka}\left({ }^{14} \mathrm{C}\right)$ & $?$ & " " \\
\hline Ksudach V & $1.8 \mathrm{ka}\left({ }^{14} \mathrm{C}\right)$ & $6 \times 3$ & Braitseva et al., 1995, 1996; Volynets et al., 1999a \\
\hline Prizrak I & Late Pleistocene (Morphology) & 6 & Melekestsev et al., 1974; Erlich, 1986 \\
\hline Prizrak II & Late Pleistocene (Morphology) & $?$ & \\
\hline Kurile Lake (-Iliinsky) & $7.6 \mathrm{ka}\left({ }^{14} \mathrm{C}\right)$ & 7 & Ponomareva et al., 2004 \\
\hline
\end{tabular}

Note: Calderas are enlisted from north to south. Roman numbers indicate a number of this caldera in a sequence of Quaternary calderas in the volcanic center.

Most of the calderas are superimposed not on individual volcanic cones but on volcanic complexes, which combine edifices of different ages.

dating efforts. Younger volcanoes preserve most of their original topography and many of them continued their activity into the Holocene [Braitseva et al., 1995].

Better age estimates are available within the range of the ${ }^{14} \mathrm{C}$ method, the last 40-45 ka. Braitseva et al. [1993] described a special technique for estimating age of volcanic deposits by dating associated paleosol horizons. A number of ${ }^{14} \mathrm{C}$-dated ignimbrites related to the large calderas fall within a period of 30-40 ka BP (a warm interstadial) (Table 2) and serve as markers for dating other volcanic deposits [Braitseva et al., 1995, 2005]. In CKD, late Pleistocene eolian sandy loams preserve tephra layers deposited during the last $40 \mathrm{ka}$. The stratigraphic position of these tephras also suggests that explosive volcanic activity peaked at $35-40$ ka BP [Braitseva et al, 2005]. It may be glacial unloading, that caused an upsurge of explosive activity at this time. On the other hand, this cluster of dates may be explained by the fact that only these ignimbrites are associated with datable paleosols, which did not form during earlier or later colder climates. The best ${ }^{14} \mathrm{C}$-dated volcanic deposits and landforms ( $>3000$ dates) are the Holocene ones, and we discuss them in a special section below. 

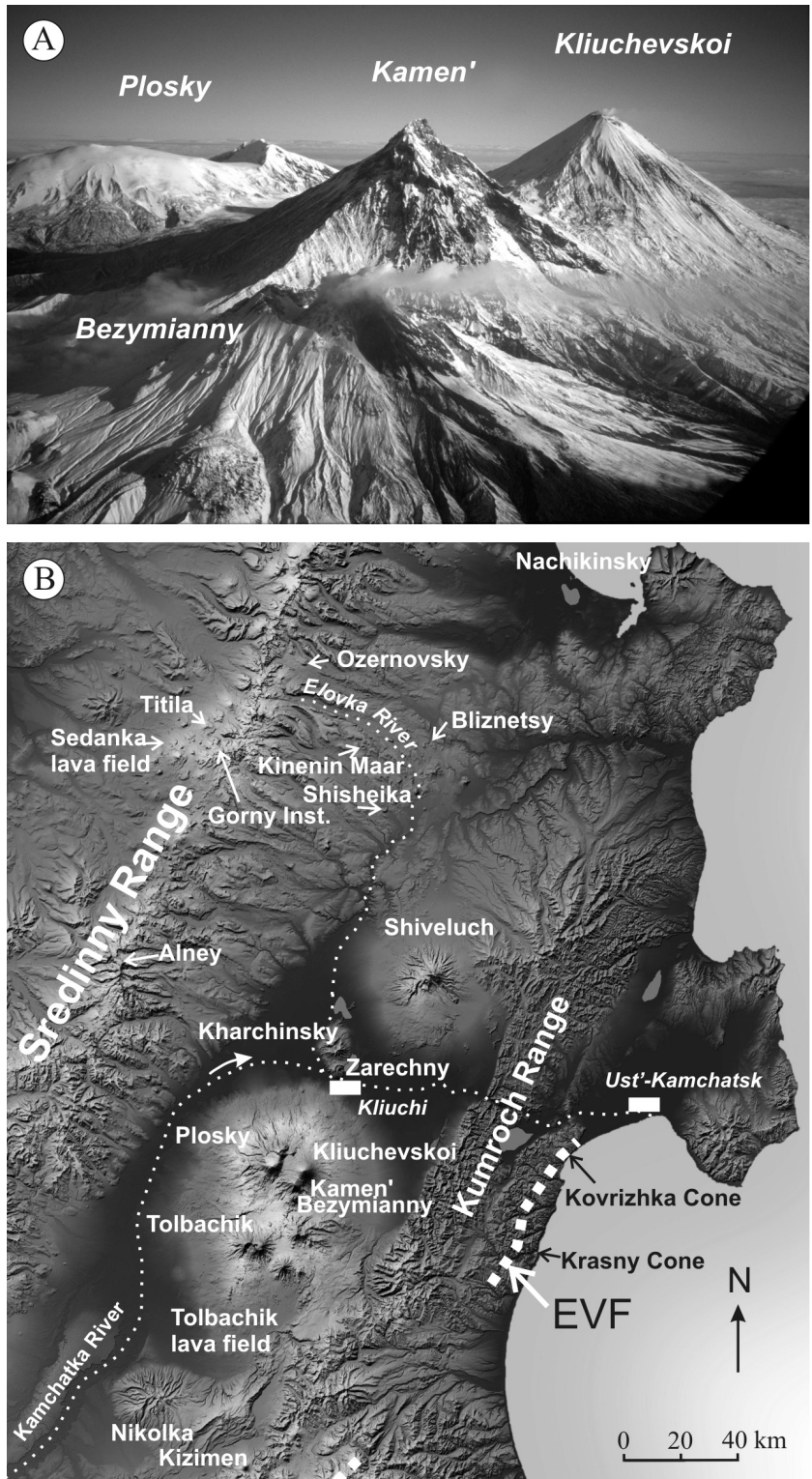

Figure 4. A. Highest volcanoes of the Kliuchevskoi group: Kliuchevskoi, $4835 \mathrm{~m}$ a.s.1.; Kamen', $4585 \mathrm{~m}$; Plosky massif with higher Plosky Blizhny, $4057 \mathrm{~m}$ (on the right), and flat Plosky Dalny (or Ushkovsky), 3903 m; Bezymianny, 2869 m a.s.l. View from the south. B. Shaded SRTM elevation model showing the volcanoes of the Central Kamchatka Depression and northern parts of EVF and Sredinny Range. A part of the image released by NASA/JPL/NIMA.

\section{HOLOCENE VOLCANISM}

Post-glacial volcanic deposits, both tephra and lava, are well preserved in Kamchatka This permits detailed reconstructions of eruptive activity over the last $10-11.5 \mathrm{ka}$. One of the main tools in the Holocene studies is a so-called soil- pyroclastic cover, which is a continuously accumulating sequence of tephra and soil layers (Fig. 6). In Kamchatka, such cover is Holocene in age: ${ }^{14} \mathrm{C}$ dates obtained for its lowermost parts commonly are as old as $\sim 9.5-10 \mathrm{ka}$, and in rare cases, go back almost to $12 \mathrm{ka}$ [Braitseva et al., 2005; Pevzner et al., 2006]. The Holocene soil-pyroclastic cover blankets most of Kamchatka, while older sequences of this kind have been mostly removed during glaciation and occur only in isolated outcrops. We ascribe a Holocene age to an eruption based on relationship of its products with the LGM deposits and presence of its tephra in the soil-pyroclastic cover. In the literature some volcanoes are ascribed to Holocene time based on "freshness" of their lava flows [e.g. Vlodavets, 1957; Ogorodov et al., 1972]. In fact, "freshness" of the lava flows depends not only on their age but also on thickness of the overlying soil-pyroclastic cover, which is accumulating faster near active volcanoes. This means that, for example, in many parts of Sredinny Range, far from most active volcanoes, a lava flow will retain its primary topography longer than, say, in Kliuchevskoi volcanic group (Fig. 7). Thus, "freshness" of volcanic landforms alone is not a sufficient criterion for determining Holocene eruptions. In addition, several cases have been reported of fresh-looking lava flows that, in fact, had been deposited over a glacier and then were "projected" onto the underlying surface when the glacier melted [Leonov et al., 1990; Ponomareva, 1990]. World catalogues of the Holocene volcanoes [e.g., Simkin and Siebert, 1994] include a lot of "fresh" volcanoes in their Kamchatka listing, especially for SR, based on old Russian publications. Re-examination of SR volcanic centers has allowed us confrim Holocene status only for some of them (Fig. 3A), [Pevzner, 2006].

\section{Distribution and Types of the Holocene Volcanic Edifices}

In Kamchatka, 37 large volcanic centers have been active during the Holocene. In addition, a few hundred monogenetic vents (cinder cones, maars, isolated craters, lava domes, etc.) were formed. Holocene eruptions took place in most of the late Pleistocene volcanic fields, excluding only few in SR (Fig. 3A).

In Kamchatka, most of the stratovolcanoes, which were active throughout Holocene, started to form either in the end of late Pleistocene or in Holocene [Braitseva et al., 1995]. Shield-like volcanoes are not typical for Holocene and likely only Titila in SR and Gorely in South Kamchatka may be termed in this way. A few Holocene volcanic edifices are composed of andesitic-rhyodacitic lava domes. Examples include Young Shiveluch, Kizimen, and Dikii Greben' volcanoes [Melekestsev et al., 1991, 1995; Ponomareva et al., 2006]. 
Some stratovolcanoes (e.g., Krasheninnikov, Fig 4, Maly Semiachik, and Bezymianny), are built of 2-4 overlapping cones. It is presumed that when the volcano reaches some elevation limit, not allowing magma to erupt through its summit crater, the magma conduit shifts and a new cone starts to form at the flanks of the earlier one. In case this shift is impossible due to limited permeability of the upper crust, a lowering of the edifice by explosion or collapse may happen, and then the activity will continue [Braitseva at al., 1980; Ponomareva, 1990].

Of 37 recently active large Kamchatka volcanoes, at least 18 have been modified by major sector collapses, some of them repetitively [Ponomareva et al., 2006]. The largest sector collapses identified so far on Kamchatka volcanoes, with volumes of $20-30 \mathrm{~km}^{3}$ of resulting debris-avalanche deposits, occurred at Shiveluch and Avachinsky volcanoes in the late Pleistocene. During the Holocene the most voluminous sector collapses have occurred on extinct Kamen' $\left(4-6 \mathrm{~km}^{3}\right)$ and active Kambalny $\left(5-10 \mathrm{~km}^{3}\right)$ volcanoes. The largest number of repetitive debris avalanches ( $>10$ during just the Holocene) occurred at Shiveluch volcano. Large failures occurred on both mafic and silicic volcanoes and were mostly related to volcanic activity.

In the Holocene, five collapse calderas associated with explosive eruptions were formed, all within the EVF: Karymsky, three calderas on Ksudach volcanic massif, and Kurile Lake caldera (Fig. 2B), (Table 2). Karymsky and Kurile Lake caldera-forming eruptions were separated by only a couple of centuries [Braitseva et al., 1997a]. Holocene ignimbrites commonly are not welded.

There are several lava fields in Kamchatka, the largest of them are the Sedanka, Tolbachik, and Tolmachev fields (Fig. 3A). Sedanka and Tolmachev cinder cones are scattered over a large territory. Mid- to late Holocene vents in the Tolbachik field form a $3-5 \mathrm{~km}$ wide belt, that stretches for $40 \mathrm{~km}$ in a SSW-NNE direction, then crosses late Pleistocene Plosky Tolbachik volcano (where it is responsible for Plosky Tolbachik's Holocene activity) and then goes for another $14 \mathrm{~km}$ to the northeast (Fig. 5B). This alignment may suggest that the position of the vents is determined by a system of faults [Piip, 1956]. Some volcanoes host many flank cinder cones, Kliuchevskoi definitely being a leader ( $>50$ cones) (Fig. 4B). Some cinder cones occur as isolated vents not associated with any large volcanoes or cone clusters (Fig. 3A).

Another type of monogenetic eruptive center in Kamchatka is large craters that have produced voluminous rhyolitic tephra falls. Three such Holocene craters are located in South Kamchatka: Chasha Crater, situated among the mafic cinder cones of the Tolmachev lava field [Dirksen et al., 2002]; Baranii Amphitheater on the ESE slope of Opala volcano; and Khodutkinsky Crater northwest of Khodutka volcano (Tables 1 and 3) [Melekestsev et al., 1996a; http://www.kscnet.ru/ivs/volcanoes/holocene]. Chasha and Khodutkinsky craters have magmas different from those of the adjacent volcanoes, while Baranii Amphitheater rhyolite fits into the overall geochemical trend for Opala volcano [Fedotov and Masurenkov, 1991]. The closest historical example of such a volcanic vent is Novarupta near Katmai volcano, Alaska [Hildreth, 1983]. Unlike Katmai, no caldera collapse was associated with these Kamchatka craters, that allowed I.V. Melekestsev [1996a] to call them "craters of sub-caldera eruptions".

\section{Ages of Volcanic Cones and How They Grow}

Reconstruction of the eruptive histories of the Holocene volcanoes based on geological mapping, tephrochronology and radiocarbon dating have allowed us to 1) determine the ages and growth rates of volcanic edifices; 2) identify temporal patterns of the eruptive activity; 3 ) document and date the largest explosive eruptions (Table 3); and 4) correlate their tephras over Kamchatka in order to obtain a tephrochronological framework for dating various deposits [Braitseva and Melekestsev, 1990; Braitseva et al., 1980, 1984, 1989, 1991, 1997a, b, 1998; Melekestsev et al., 1995, 1996b; Ponomareva, 1990; Ponomareva et al., 1998, 2004, 2007; Selyangin and Ponomareva, 1999; Volynets et al., 1989, 1999a].

Ages of some stratovolcanoes were determined based on the assumption that initial construction of such edifices was by continuous explosive activity. At the foot of all the Holocene stratovolcanoes we have identified tephra packages that meet the following criteria: 1) they underlie the oldest lava flows from the volcano; 2) are widely dispersed and easily identified around the volcano; 3 ) consist of a number of individual layers sometimes separated by thin sandy loam horizons; and 4) overlie thick paleosol layers suggesting that no activity from the volcano took place earlier. Radiocarbon dates on such paleosols or other associated organic matter have allowed us to date these tephra packages and thus constrain when cone-building eruptions started on various eruptive centers (Table 4). Ages of Kizimen and Dikii Greben extrusive volcanoes have been estimated based on the stratigraphic position of their initial tephra relative to the LGM deposits and the 7.6 ka Kurile Lake caldera ignimbrite, respectively.

Growth rates have been estimated for some stratovolcanoes [Braitseva et al., 1995]. The largest Holocene volcano, Kliuchevskoi ( $\sim 800 \mathrm{~m}$ a.s.1.) started to form at $1700 \mathrm{~m}$ on the slope of Kamen' volcano at $\sim 5.9 \mathrm{ka}\left({ }^{14} \mathrm{C}\right.$ ) (or $\sim 6.8$ calibrated $\mathrm{ka}$ ) and likely reached its modern height within about 3000 years, after which its first flank vents 

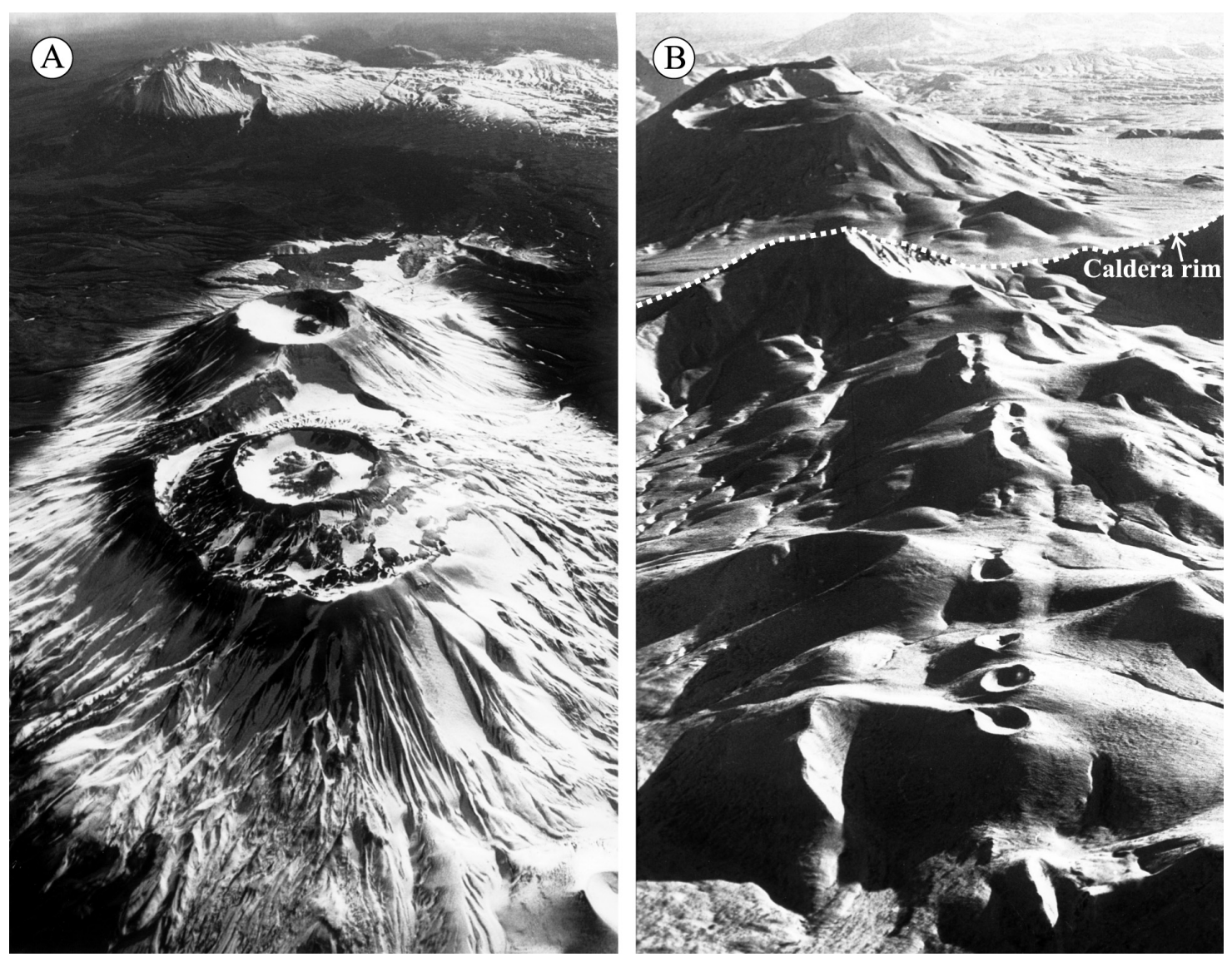

Figure 5. A. Krasheninnikov volcano, view to the south. This Holocene volcano is nested in a $235-38$ ka old caldera and consists of two large coalesced cones. The northern cone is crowned with a caldera enclosing a smaller cone with a lava cone inside. Large cones as well as numerous monogenetic vents north and south of the late Pleistocene caldera are aligned along the regional fault zone parallel to the general strike of the volcanic belt [Florensky and Trifonov, 1985]. B. Cinder cones north of Krasheninnikov caldera. The cones are aligned along the regional fault zone. Krasheninnikov volcano is in the background. Photos courtesy Vasilii Podtabachny.

started to form. This is about the duration of the main cone-building phase for other large volcanoes (Young Cone of Avachinsky, North Cone of Krasheninnikov, Karymsky, etc.). Small edifices with volumes of $\sim 2 \mathrm{~km}^{3}$, e.g. each of the two cones composing Kikhpinych volcano or Stübel Cone in Ksudach massif, formed in the main during a few hundred years.

Eruptive activity of all the studied volcanoes was organized in spurts, with alternating active and repose periods. Repose periods as long as 1000-3000 years were rather common. Longer repose periods with the durations of $>3000$ years occurred at Bezymianny, Kikhpinych, Zheltovsky, Dikii Greben', and Kambalny volcanoes [Melekestsev et al., 2001]. The longest known period of quiescence $(\sim 3500$ years), after which the volcano was able to resume its activity, was at Dikii Greben' volcano [Ponomareva et al., 2006]. Even volcanoes notable for their frequent historic eruptions and intense magma supply like Shiveluch or Avachinsky appeared to have had $\sim 900$ years-long repose periods (or at least periods of low activity) [Braitseva et al., 1998; Ponomareva et al., 2007]. Zones of cinder cones behaved much as the large volcanoes: their eruptions tended to cluster into active periods separated by quiescence not exceeding 3000-4000 years [Braitseva et al., 1984; Dirksen and Melekestsev, 1999]. In certain cases, we can identify long periods of volcanic rest shared by several neighboring volcanoes. For example, three such periods recorded by thick paleosols have been documented for the southernmost part of Kamchatka, which hosts five active volcanoes (Zheltovsky, Iliinsky, Dikii Greben', Koshelev and Kambalny). The earlier two periods of quiescence lasted for a minimum of 1400 to 1500 years, and the latest one-for 750 years [Ponomareva et al., 2001]. Long (up to 3500 years) repose periods do not seem 
Table 3. The largest explosive eruptions in Kamchatka during the last 10,000 years

\begin{tabular}{|c|c|c|c|c|}
\hline Source volcano & Tephra code & $\begin{array}{c}\text { Average }{ }^{14} \mathrm{C} \text { age, } \\
\text { yr BP (or calendar } \\
\text { age for historical } \\
\text { eruptions) }\end{array}$ & $\begin{array}{l}\text { Volume of } \\
\text { tephra, } \mathrm{km}^{3}\end{array}$ & Composition of tephra \\
\hline \multirow[t]{19}{*}{ Shiveluch } & $\mathrm{SH}_{1964}$ & AD 1964 & $0.6-0.8$ & Andesite \\
\hline & $\mathrm{SH}_{1854}$ & AD 1854 & $\sim 1$ & " " \\
\hline & $\mathrm{SH}_{1}$ & 250 & $\geq 2$ & " " \\
\hline & $\mathrm{SH}_{2}$ & 950 & $\geq 2$ & " " \\
\hline & $\mathrm{SH}_{3}$ & 1400 & $\geq 2$ & " " \\
\hline & $\mathrm{SH}_{1450}$ & 1450 & $\geq 2$ & " " \\
\hline & $\mathrm{SH}_{5}$ & 2550 & $\sim 1$ & " " \\
\hline & $\mathrm{SH}_{2800}$ & 2800 & $\geq 1$ & " " \\
\hline & SHsp & 3600 & $\sim 1$ & Basalt \\
\hline & $\mathrm{SH}$ & 3750 & $\geq 1$ & Andesite \\
\hline & SHdv & 4100 & $\geq 2$ & " " \\
\hline & $\mathrm{SH}_{4700}$ & 4700 & $\geq 2$ & " " \\
\hline & $\mathrm{SH}_{4800}$ & 4800 & $\geq 2$ & " " \\
\hline & $\mathrm{SH}_{5600}^{4800}$ & 5600 & $\geq 1$ & " " \\
\hline & $\mathrm{SH}_{6850}$ & 6850 & 1.2 & " " \\
\hline & $\mathrm{SH}$ & 7900 & $\geq 1$ & " " \\
\hline & $\mathrm{SH}$ & 8100 & $\geq 2$ & " " \\
\hline & $\mathrm{SH}$ & 8200 & $\geq 1$ & " " \\
\hline & SH & 8300 & $\geq 2$ & " " \\
\hline Bezymianny & $\mathrm{B}_{1956}$ & AD 1956 & $1.8-2$ & " " \\
\hline Kizimen & $\mathrm{KZ}$ & 7550 & $4-5$ & Dacite \\
\hline Khangar & KHG & 6850 & $14-16$ & Dacite-rhyodacite \\
\hline Karymsky caldera & KRM & 7900 & $13-16$ & Rhyodacite \\
\hline \multirow[t]{6}{*}{ Avachinsky } & II $\mathrm{AV}_{3}$ & 3300 & $>1.2$ & Basaltic andesite \\
\hline & II AV ${ }_{1}\left(\mathrm{AV}_{1}\right)$ & 3500 & $\geq 3.6$ & " " \\
\hline & $\mathrm{IAv} 24\left(\mathrm{AV}_{2}\right)$ & 4000 & $\geq 0.6$ & Andesite-basaltic andesite \\
\hline & $\mathrm{IAv} 20\left(\mathrm{AV}_{3}\right)$ & 4500 & $\geq 1.1$ & Andesite \\
\hline & IAv12 $\left(\mathrm{AV}_{4}\right)$ & 5500 & $\geq 1.3$ & " " \\
\hline & IAv2 & 7150 & $\geq 8-10$ & " " \\
\hline Chasha Crater & OPtr & 4600 & $0.9-1$ & Rhyolite \\
\hline \multicolumn{5}{|l|}{ Opala, Baranii } \\
\hline Amphitheater Crater & $\mathrm{OP}$ & 1500 & $9-10$ & " " \\
\hline Khodutkinsky Crater & KHD & 2500 & $1-1.5$ & Rhyodacite \\
\hline \multirow[t]{2}{*}{ Ksudach, Stübel cone } & $\mathrm{KSht}_{3}$ & AD 1907 & $1.5-2$ & Basaltic andesite-dacite \\
\hline & $\mathrm{KSht}_{1}{ }_{1}$ & 950 & $0.8-1$ & " " \\
\hline \multirow[t]{4}{*}{ Ksudach calderas } & $\mathrm{KS}_{1}$ & 1800 & $18-19$ & Rhyolite \\
\hline & $\mathrm{KS}_{2}$ & 6000 & $7-8$ & Andesite \\
\hline & $\mathrm{KS}_{3}$ & 6350 & $0.5-1$ & Rhyodacite-andesite \\
\hline & $\mathrm{KS}_{4}$ & 8850 & $1.5-2$ & Andesite \\
\hline Iliinsky & ZLT & 4850 & $1.2-1.4$ & " " \\
\hline Kurile Lake caldera & $\mathrm{KO}$ & 7600 & $140-170$ & Rhyolite-basaltic andesite \\
\hline
\end{tabular}

Note: Volcanoes are enlisted from north to south. Radiocarbon ages are averaged to nearest 50 yrs. Original ages are from Bazanova and Pevzner, 2001; Bazanova et al., 2004; Braitseva et al., 1997a,b, 1998; Dirksen et al., 2002; Pevzner et al., 1998; Ponomareva et al., 2004, 2007, and Zaretskaya et al., 2007. For Avachinsky eruptions new tephra codes are from Bazanova et al., 2004, and old codes (in parentheses) are from Braitseva et al., 1997a,b; 1998.

to exhibit any specific chemical or spatial association. Data on the Holocene eruptive histories of Kamchatka volcanoes show that long repose periods can occur both at dominantly basaltic (e.g. Kikhpinych) and rhyodacitic (Dikii Greben') volcanoes, dominantly explosive (e.g. Ksudach) and effusive (Dikii Greben') volcanoes, and those located closer to the Kamchatka trench (Kikhpinych) and farther west (Kizimen) [Melekestsev et al., 2001]. 

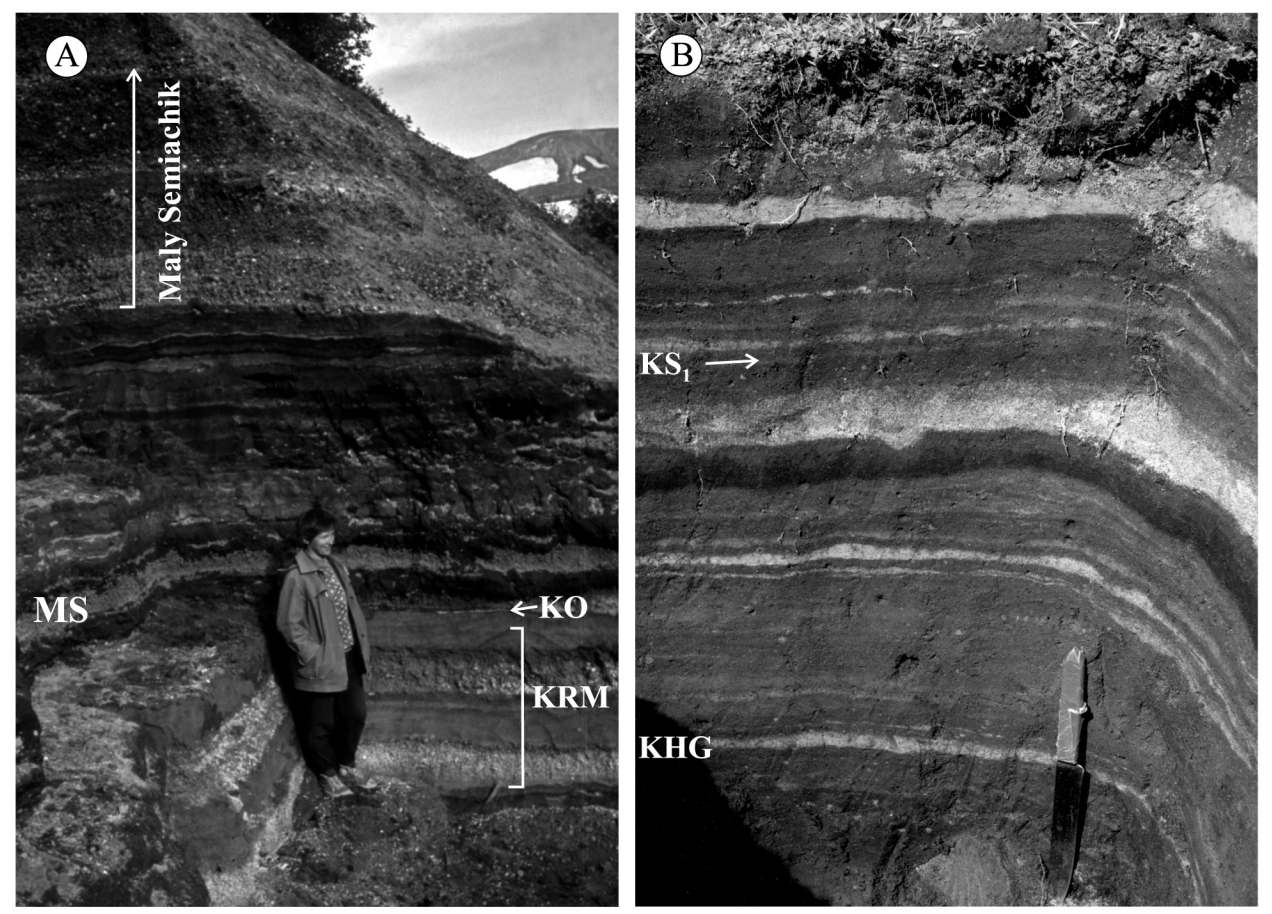

Figure 6. Holocene soil-pyroclastic cover in Kamchatka. A. EVF, Maly Semiachik volcano region. Local tephra: MS - cinder of the initial cone-building eruptions from Kaino-Semiachik, the youngest cone of Maly Semiachik volcano (7300-7400 ${ }^{14} \mathrm{C}$ yr BP); Maly Semiachik - stratified cinders from Kaino-Semiachik ( $\sim 4000{ }^{14} \mathrm{C}$ yr BP). Regional marker tephras: KRM - a package of the Karymsky caldera deposits (7900 ${ }^{14} \mathrm{C}$ yr BP); KO - a thin ash layer from the Kurile Lake caldera $\left(7600{ }^{14} \mathrm{C}\right.$ yr BP). A person is $\sim 155 \mathrm{~cm}$ tall. Photo courtesy Oleg Seliangin. B. Northern part of Sredinny Range, Sedanka lava field. Regional marker tephras: KHG - Khangar volcano ( $6850{ }^{14} \mathrm{C}$ yr BP). $\mathrm{KS}_{1}-\mathrm{Ksudach}(1800$ ${ }^{14} \mathrm{C}$ yr BP). A knife is $\sim 25 \mathrm{~cm}$ long.

\section{Largest Explosive Eruptions}

Table 3 lists major Holocene explosive eruptions in Kamchatka. Large eruptions took place in various parts of Kamchatka (Table 3), (Fig. 3A). The largest eruption was associated with formation of Kurile Lake caldera and yielded a tephra volume of $140-170 \mathrm{~km}^{3}$, making it the largest Holocene eruption in the Kurile-Kamchatka volcanic arc and ranking it among Earth's largest Holocene explosive eruptions. Tephra from the Kurile Lake caldera-forming eruption was dispersed mostly to the northwest at a distance of $\sim 1700 \mathrm{~km}$ [Ponomareva et al., 2004]. The second largest explosive Holocene eruption was associated with a caldera at Ksudach $\left(\mathrm{KS}_{1}\right)$ (Table 3). Its tephra was dispersed to NNE and covered most of Kamchatka providing a wonderful marker for Holocene studies [Braitseva et al., 1996, 1997b]. Tephras associated with other caldera-forming and larger sub-caldera eruptions reached volumes of 9-19 $\mathrm{km}^{3}$. Most large tephras ranged from andesite to rhyolite in composition. The only large mafic (basaltic andesite) tephra erupted from Avachinsky volcano and yielded a volume of $\geq 3.6 \mathrm{~km}^{3}$.
Dated tephra layers are widely used for dating and correlating various volcanic and non-volcanic deposits [Braitseva et al., 1997b] as well as archaeological sites [Braitseva et al., 1987] and serve as a main tool in reconstructing eruptive histories of the Holocene volcanoes [Braitseva and Melekestsev, 1990; Braitseva et al., 1980, 1984, 1989, 1991, 1998; Melekestsev et al., 1995; Ponomareva, 1990; Ponomareva et al., 1998, 2004, 2007; Selyangin and Ponomareva, 1999; Volynets et al., 1989, 1999a], paleoseismic events (tsunami and faulting) [Pinegina et al., 2003; Bourgeois et al., 2006; Kozhurin et al., 2006], and environmental change [e.g. Dirksen, 2004]. As of now, no Kamchatka tephra has been positively identified in the Greenland ice cap, but some peaks in the GISP-2 core have been tentatively correlated with the largest Kamchatka eruptions based on age estimates [Braitseva et al., 1997a]. Finding the Aniakchak tephra from Alaska in Greenland ice [Pearce et al., 2004] suggests the possibility of finding Kamchatka tephras there as well.

In Figure 8, there are two peaks of magma output in explosive eruptions at AD 200-700 and BC 6650-4900, with 


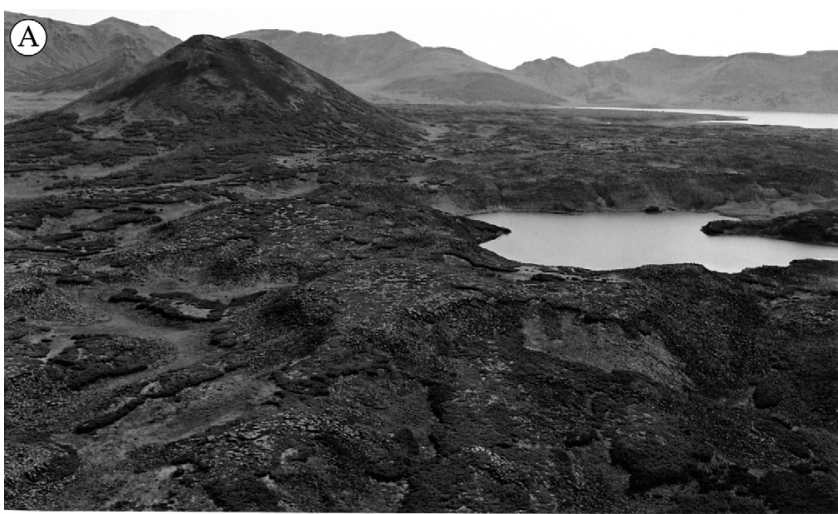

(B)

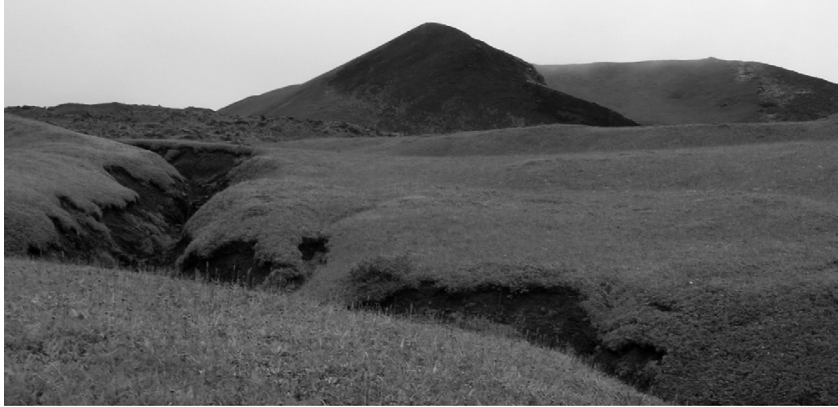

Figure 7. A. Late Pleistocene cinder cone and lava flow in the central part of Sredinny Range. Both cinder cone and lava flow look very fresh; however, tephra of this eruption is not present in the soil-pyroclastic cover. Lava is bare in many places, but soilpyroclastic cover can be found in the depressions on its surface and is as old as that overlying the LGM deposits. B. Flat surface on the foreground is a $\sim 2 \mathrm{ka}$ old lava flow overlain by more than a $3 \mathrm{~m}$ thick soil-pyroclastic cover (Kliuchevskoi volcano foot). Original topography of the lava flow is smoothed and lava crops out mostly in the river valleys. A young lava flow likely formed in late 1800ies is at the far left. A $\sim 3.5 \mathrm{ka}$ old cinder cone is at the right.

especially high production between BC 6600 and 6400 (“a century of catastrophes" [Melekestsev et al., 1998]). During these peaks, larger eruptions are relatively more frequent, whereas the frequency of all eruptions (above some certain size level, say, $1 \mathrm{~km}^{3}$ ) remains near average [Gusev et al., 2003]. Considering the general temporal structure of the event sequence, one can say that in the discussed timeordered list of eruptive volumes, large-size explosive eruptions happen in tight clusters "too often" (as compared to a randomly-shuffled list of the same events). The reality of this tendency was successfully checked by statistical analysis and is called "order clustering" of the largest explosive eruptions [Gusev et al., 2003].

In addition, we analyzed magma output rate averaged over small time intervals. We found that this rate, as a function of time (at time scales 300-10,000 yrs), has a well-expressed episodic character. This fact contradicts commonly assumed random or periodic temporal distribution of eruptions [e.g. Wickman, 1966; Ho et al., 1991; Jones et al., 1999] and supports qualitative conclusions about non-uniform or episodic character of volcanism derived from the distribution of tephra layers in deep-sea boreholes [Kennet et al. 1977; Cambray and Cadet, 1996; Cao et al., 1995; Prueher and Rea, 2001$]$ or from the on-land tephrostratigraphy [Braitseva et al., 1995].

Mafic intrusion into a silicic magma chamber has been proved to be a common trigger for an explosive eruption [Sparks and Sigurdsson, 1977]. In Kamchatka, cases of such triggering have been demonstrated for most of the large explosive eruptions [e.g., Volynets, 1979; Melekestsev et al., 1995; Volynets et al., 1999a; Eichelberger and Izbekov, 2000; Ponomareva et al., 2004]. So the observed clusters of larger explosive eruptions over a large territory might have been caused by large-scale changes in the crustal stress field that have allowed an ascent of deeper mafic melts over most of the Kamchatka volcanic region. A typical explanation of such a phenomenon is glacial unloading [Wallman et al., 1988], but it hardly can be applied to the younger of the two Kamchatka volcanic peaks (AD 200-700). We hope that further detailed studies of spatialtemporal patterns of the well-dated Holocene Kamchatka volcanism combined with the records of the largest crustal and subduction-related earthquakes will allow us to explain its episodic character.

\section{Volcanic Hazard Assessment}

Volcanic hazard assessment has been implemented for many Holocene volcanoes based on their reconstructed eruptive histories [e.g. Melekestsev et al., 1989; Ponomareva and Braitseva, 1991; Bazanova et al., 2001]. About $80 \%$ of the $\sim 350,000$ people inhabiting Kamchatka concentrate in three cities: Petropavlovsk-Kamchatsky and Elizovo, located $\sim 30 \mathrm{~km}$ south of Koriaksky and Avachinsky volcanoes, and Kliuchi, located $30 \mathrm{~km}$ north of Kliuchevskoi and 45 $\mathrm{km}$ south of Shiveluch volcanoes. For the historical period ( $\sim 300$ years), these sites have experienced volcanic influence only by minor ashfalls and flooding in outermost suburbs. During the Holocene, the main hazard for these territories was also associated with tephra falls and lahars. Recurrence of large tephra falls (with thickness of buried tephra $\geq 1 \mathrm{~cm}$ ) in Petropavlovsk-Kamchatsky during the last 8000 yrs was $\sim 1$ fall per 420 yrs [Bazanova et al., 2005]. In Kliuchi (Fig. 2A), an average recurrence of large tephra falls in Holocene was $\sim 1$ fall per 700 years; however, it reached a value of 1 per 300 years during the last 1000 years [Pevzner et al., 2006]. Such remote towns as Ust'-Bolsheretsk received only 
Table 4. Radiocarbon ages of some volcanic edifices

\begin{tabular}{|c|c|c|}
\hline Volcano & $\begin{array}{l}\text { Onset of edifice } \\
\text { formation, } \\
\text { yr B.P. }\left({ }^{14} \mathrm{C}\right)\end{array}$ & Reference \\
\hline Kliuchevskoi & $\sim 5900$ & Braitseva et al., 1995 \\
\hline pre-Bezymianny & $10,000-11,000$ & Braitseva et al., 1991; Braitseva et al., 1995 \\
\hline Bezymianny & $\sim 4700$ & " " \\
\hline Kizimen & $12,000-11,000$ & Braitseva et al., 1995; Melekestsev et al., 1995 \\
\hline Komarov & 1500 & Ponomareva, 2000, unpublished data \\
\hline Gamchen (Baranii Cone) & 3600 & Ponomareva et al., 2006 \\
\hline Krasheninnikov & & Ponomareva, 1990; Braitseva et al., 1995 \\
\hline North Cone & 5500 & " " \\
\hline Mid-North Cone & 1300 & \\
\hline Kikhpinych & & Braitseva et al., 1989; Braitseva et al., 1995 \\
\hline West Cone & 4200 & 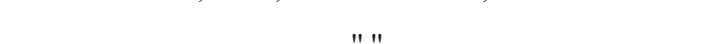 \\
\hline Savich Cone & 1400 & \\
\hline \multicolumn{3}{|l|}{ Maly Semiachik } \\
\hline Paleo-Semiachik & $20,000 ?$ & \\
\hline Meso-Semiachik & 11,000 & Braitseva et al., 1980, 1995; Melekestsev et al., 1989 \\
\hline Kaino-Semiachik & $7300-7400$ & \\
\hline Karymsky & 5300 & Braitseva and Melekestsev, 1990; Braitseva et al., 1995 \\
\hline Avachinsky (Young Cone) & 3500 & Braitseva et al., 1995; Bazanova et al., 2003 \\
\hline Ksudach (Stübel Cone) & 1600 & Braitseva et al., 1995; Volynets et al., 1999a \\
\hline Iliinsky & 7600 & Ponomareva et al., 2004 \\
\hline Dikii Greben' & 7600 & (1) \\
\hline
\end{tabular}

two large tephra falls during the last 8500 years [Bazanova et al., 2005]. A long-term prediction of sector collapses on Kliuchevskoi, Avachinsky and Koriaksky volcanoes [Melekestsev and Braitseva, 1984; Melekestsev et al., 1992] highlights the importance of closer studies of their structure and stability.

\section{AMOUNT OF ERUPTED MATERIAL}

Estimates of the eruptive volumes and mass were done based on the detailed maps of the late Pleistocene-Holocene volcanoes compiled by I.V.Melekestsev. The total mass of rocks erupted during the late Pleistocene-Holocene is estimated at 18 to $19 \times 10^{12}$ tonnes [Melekestsev, 1980]. CKD volcanic belt was the most productive ( $\sim 40 \%$ of all the eruptives) (Fig. 9A). The EVF production was less at $35 \%$. SR $(25 \%)$ was subordinate to both other belts. Mafic rocks dominated in all the belts. Andesite-rhyolite constituted $25-30 \%$ of the total volume erupted in CKD and EVF and only $\sim 6 \%$ of that erupted in Sredinny Range. Within EVF, most of silicic rocks were erupted in South Kamchatka. In Holocene, CKD and EVF belts produced almost similar amount of eruptives, while SR belt productivity dropped (Fig. 9A).

The highest magma production rate both during the last 60 and $11.5 \mathrm{ka}$ was in CKD (Fig. 9B). In late Pleistocene, production rate in CKD and EVF was almost twice higher than that in Holocene. Late Pleistocene magma production rate in SR was smaller than that in CKD and EVF, but not that dramatically smaller than in Holocene. It is unclear whether this Holocene drop in SR production rate means the end of volcanic activity in SR or just reflects a relatively quiet period.

The largest late Pleistocene-Holocene stratovolcanoes yielded volumes up to $320 \mathrm{~km}^{3}$ or mass of $\sim 0.74 \times 10^{12}$ tonnes (including tephra) [Melekestsev, 1980]. Examples include Kronotsky, Kamen', and Old Avachinsky (before the sector collapse). The largest Holocene edifice is that of Kliuchevskoi $\left(270 \mathrm{~km}^{3}\right.$ or $0.6 \times 10^{12}$ tonnes). The smallest Holocene stratovolcano, Stübel Cone, has a volume of $\sim 2$ $\mathrm{km}^{3}$ and mass of the rocks of $\sim 0.005 \times 10^{12}$ tonnes. The largest Holocene explosive eruption produced $140-170 \mathrm{~km}^{3}$ $\left(0.18 \times 10^{12}\right.$ tonnes $)$ of tephra and 7-km-wide Kurile Lake caldera [Ponomareva et al., 2004]; other eruptions ranked far below (Table 3). Most of the late Pleistocene calderas are significantly larger (up to $18 \mathrm{~km}$, Table 2) and are surrounded by thick packages of welded tuffs. We suggest that most of the late Pleistocene caldera-forming eruptions were at least equal to the largest Holocene eruption (Kurile Lake caldera) or larger. Volume of individual Holocene lava eruptions reached 2-5 km³ [Pevzner et al., 2000; Ponomareva et al., 2006]. 


\section{COMPOSITION OF ROCKS}

Late Pleistocene-Holocene volcanic rocks in Kamchatka cover wide range of compositions. One of their most interesting features is a high proportion of mafic varieties (basaltandesite) compared to that of silicic rocks (Fig. 9); [Volynets, 1994]. The amount of the sedimentary component is limited in most of the Kamchatka volcanic rocks [Kersting and Arculus, 1995; Tsvetkov et al., 1989; Turner et al., 1998] and the most mafic varieties do not show any sign of crustal contamination [e.g. Volynets et al., 1994; Dorendorf et al., 2000a], offering a chance to investigate a relatively simple system. In addition, a certain amount of more silicic rocks (dacite-rhyolite) is present in Kamchatka, mostly related to caldera systems and associated crustal magma chambers. Studies of magma evolution on the individual centers show that most of the silicic rocks have been derived from mafic melts through fractionation and mixing with related melts [e.g. Kadik et al., 1986; Ivanov, 1990; Volynets et al., 1989, 1999a; Leonov and Grib, 2004]. O and Sr isotopes studies, however, have shown that some of silicic rocks have been influenced by crustal and meteoritic/hydro-thermal water
[Bindeman et al., 2004]. In this paper, we discuss mafic products since these are most reflective of mantle processes.

Large variations of the volcanic rocks in Kamchatka and adjacent volcanic arcs clearly represent the result of several factors that control conditions of the mantle melting and future melt evolution during ascent and chamber residence before eruption. These factors may vary from arc to arc and are mainly related to crustal thickness, mantle fertility, composition and thermal state of the subducted plate [Pearce and Parkinson, 1993; Plank and Langmuir, 1988, 1993], temperature of the mantle wedge and subducted slab [England et al., 2004; Manea et al., 2005], and the amount and compositions of subducted fluids and sediments [Plank and Langmuir, 1993; Duggen et al., 2007].

\section{Cross-arc Chemical Zonation}

Cross-arc chemical zonation of the Late PleistoceneHolocene Kamchatka volcanic rocks from east to west at different latitudes is most pronounced in their enrichment in alkalies and incompatible trace elements [Volynets, 1994; Tatsumi et al., 1995; Avdeiko et al., 2006; Davidson, 1992,

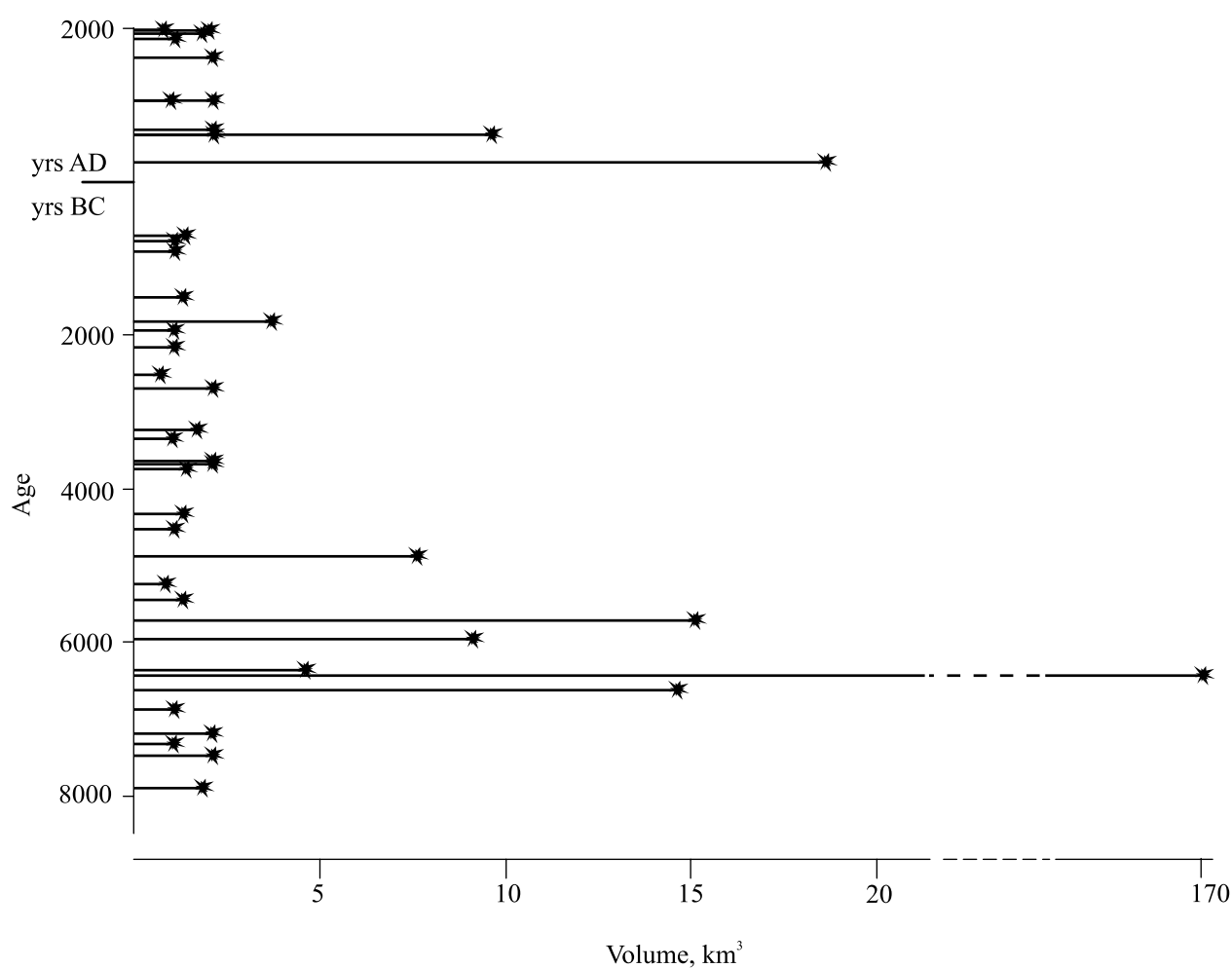

Figure 8. Volumes of the products from the largest explosive eruptions in Kamchatka in Holocene (for details see Table 3). Ages are radiocarbon ages converted to calibrated years (cal yr BP) using CALIB 5.0 [Stuiver et al., 2005]. Two peaks of magma output in explosive eruptions can be identified at AD 200-700 and BC 6650-4900, with especially high production between BC 6600 and 6400 ("a century of catastrophes" [Melekestsev et al., 1998]). 
(A)

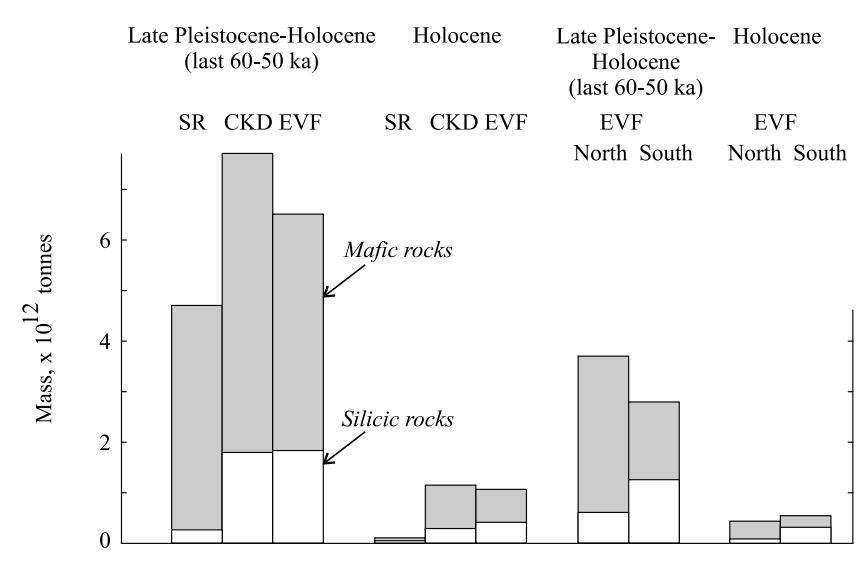

(B) Magma production rate

Late Pleistocene-Holocene Late Pleistocene Holocene (last 60-50 ka) (between 60-50 and

$11.5 \mathrm{kaBP}$

SR CKD EVF

SR CKD EVF

SR CKD EVF

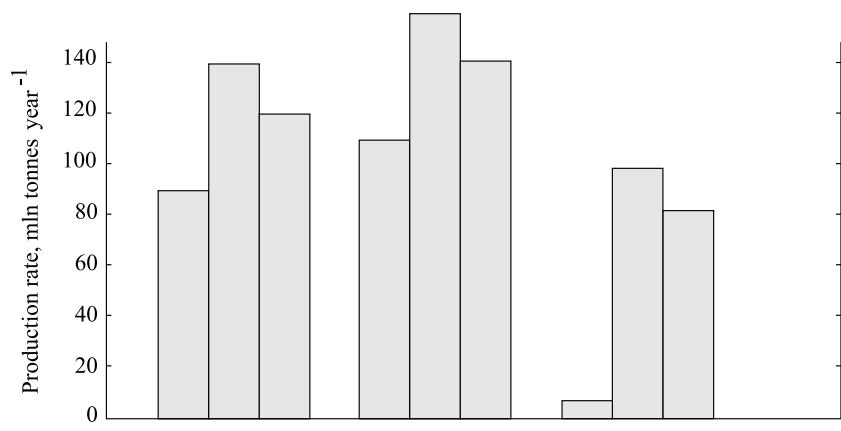

Figure 9. Mass of the late Pleistocene- Holocene erupted rocks (A) and magma production rate (B) by volcanic belts: SR - Sredinny Range, CKD - Central Kamchatka Depression, EVF - Eastern volcanic front. In A, gray and white fillings show mafic and silicic rocks, respectively. CKD was the most and SR - the least productive volcanic belts in Kamchatka during late Pleistocene-Holocene.

pers.comm.]. Some authors argue that the currently active subduction zone may be responsible for all the magmagenerating processes during this period [Tatsumi et al., 1995; Churikova et al., 2001]. Others suggest the simultaneous existence of two subduction zones: one beneath the Eastern Volcanic Front and the Central Kamchatka Depression and the second one beneath the Sredinny Range [Avdeiko et al., 2006].

To evaluate both hypotheses, mafic volcanic rocks densely sampled along an E-W transect have been studied for major and trace element compositions as well as isotopes of $\mathrm{Sr}, \mathrm{Nd}$, $\mathrm{Pb}, \mathrm{U}, \mathrm{Th}, \mathrm{O}$ and Hf [Churikova et al., 2001; Dorendorf et al., 2000a, b; Münker et al., 2004; Wörner et al., 2001]. This $220-\mathrm{km}$-long transect is comprised by 13 Upper Pleistocene and Holocene stratovolcanoes and two large lava fields. It stretches from EVF through CKD into the back arc of SR (Fig. 3B). Since the compositions of CKD rocks north and south of the Kamchatka River are significantly different, we consider them separately as NCKD and SCKD, respectively. The transect was fitted to follow the widest possible crossarc extent of recent volcanism, which is one of the widest worldwide.

In terms of major element composition the rocks of the EVF belong to the low- to medium-K tholeiitic and calcalkaline series (Fig. 10). Low-K rocks stretch along the EVF and are present on the other volcanoes closest to the trench (Kronotsky, Kikhpinych, some volcanoes of Bolshoi Semiachik massif, Zhupanovsky, Avachinsky, Mutnovsky, Khodutka, Ksudach, Zheltovsky, Kambalny) (Fig. 3B), (Table 1); [e.g. Fedotov and Masurenkov, 1991; Duggen at el., 2007]. The rocks of the back arc (SR) are medium to high-K calc-alkaline. SCKD and NCKD rocks have intermediate position between EVF and SR. Near Ichinsky volcano, we found HFSE (high field strength elements)-enriched basalts with intra-plate affinities (here: basalts of withinplate type - WPT). Recent studies have discovered rocks of this type in northern parts of Sredinny Range [Volynets et al., 2005]. Some more alkaline rocks (shoshonitic and K-alkaline basaltoids, alkaline basalts and basanites) were described in SR [Perepelov et al., 2005]. Those will not be considered in the following discussion, however, because they belong to Paleogene and Miocene.

Trace elements patterns for EVF, CKD and SR rocks are shown in (Fig. 11). All rocks have typical arc-signatures with strong but variable LILE and LREE enrichment and low HFSE. LILE and HFSE concentrations increase from the front to the back-arc. All rocks are depleted in $\mathrm{Nb}$ and $\mathrm{Ta}$, REE, and HREE compared to NMORB. However, Nb-Tadepletions in back arc rocks compared to neighboring LILE's are much smaller than in the EVF and CKD rocks. All the SR rocks contain a variable amount of the enriched OIB-like mantle component. The amount of this component changes from low addition on Ichinsky volcano (so called SR (IAB)) to highly enriched (up to 30-35\%) in intra-plate basalts (so called SR (WPT)) [Churikova at al., 2001, 2007; Münker et al., 2004; Volynets et al., 2006].

Along the transect under study the depth to the slab changes from $100 \mathrm{~km}$ for EVF to $400 \mathrm{~km}$ for SR [Gorbatov et al., 1997]. Some CKD samples are close to a primary mantlederived melt composition. However, EVF and SR rocks and most of CKD rocks were obviously affected by some mineral fractionation, therefore, direct comparison of trace element concentrations is impossible. For comparison, the data from each volcano were normalized to $6 \% \mathrm{MgO}$ following the approach used by [Plank and Langmuir, 1988]. The normalized data for selected trace elements and element ratios versus 
depth to the slab surface are shown in Figures 12 and 13. Most of incompatible trace elements, i.e. HFSE ( $\mathrm{Zr}, \mathrm{Nb}, \mathrm{Hf}, \mathrm{Ta}$ ), LILE ( $\mathrm{Sr}, \mathrm{Ba}, \mathrm{Rb}, \mathrm{Be}, \mathrm{Pb}, \mathrm{U}$, Th), LREE, some major elements $(\mathrm{K}, \mathrm{Na})$ and certain element ratios $(\mathrm{K} / \mathrm{Na}, \mathrm{La} / \mathrm{Yb}, \mathrm{Sr} / \mathrm{Y}, \mathrm{Nb} /$ $\mathrm{Yb}$ ) are positively correlated with slab depth. Similar cross-arc changes in element concentrations and their ratios have been recently found south of the described transect [Duggen et al., 2007; Portnyagin et al., 2007a]. At the same time Y and the HREE are almost constant from front to back arc (Fig. 12H".
The WPT at Ichinsky have higher concentrations of $\mathrm{Na}_{2} \mathrm{O}$, $\mathrm{TiO}_{2}, \mathrm{P}_{2} \mathrm{O}_{5}$, Sr and all HFSE and REE, and are depleted in $\mathrm{SiO}_{2}$ and $\mathrm{Rb}$ compared to the Ichinsky IAB-SR.

Isotope data for the northern transect are summarized in Figure 14. The data plot close to the MORB field; variations in all isotope systems are small and inside the previously reported ranges for Kamchatka [Kepezhinskas et al., 1997; Kersting and Arculus, 1995; Tatsumi et al., 1995; Turner et al., 1998]. There is a general increase in ${ }^{87} \mathrm{Sr} /{ }^{86} \mathrm{Sr}$ and ${ }^{143} \mathrm{Nd} /{ }^{144} \mathrm{Nd}$ from

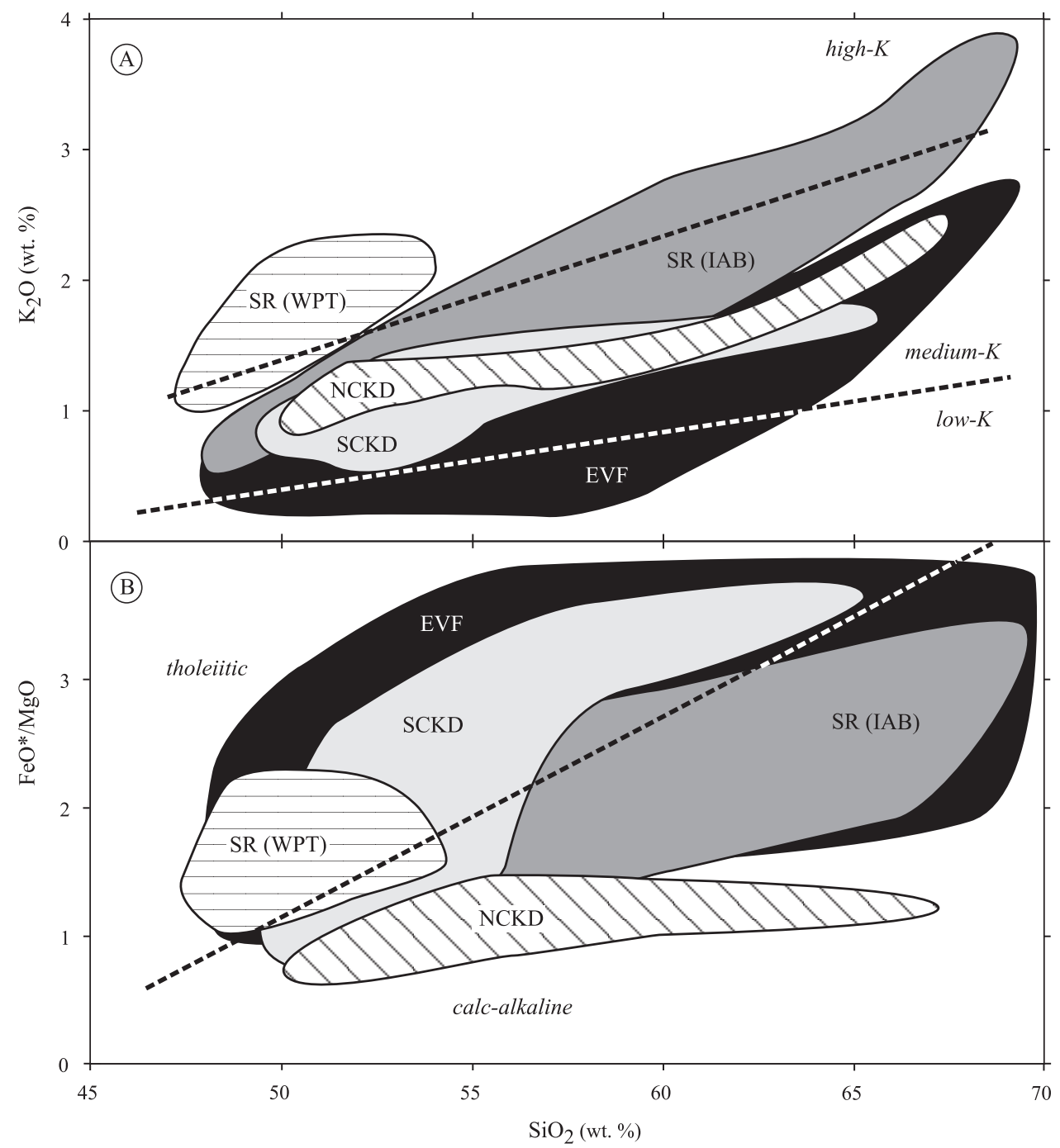

Figure 10. $\mathrm{K}_{2} \mathrm{O}(\mathbf{A})$ and $\mathrm{FeO} * \mathrm{MgO}(\mathbf{B})$ vs. $\mathrm{SiO}_{2}$ for late-Pleistocene-Holocene volcanic rocks of the Kamchatka Peninsula. The rocks of different volcanic regions or of specific composition are combined in the fields marked by different colors. Only medium-K calk-alkaline rocks are shown for SCKD region. Data from Fedotov and Masurenkov [1991]; Dorendorf et al. [2000a, 2000b]; Churikova et al. [2001]; Leonov and Grib [2004]; Ivanov et al. [2004]; Volynets et al. [2005]. EVF - Eastern Volcanic Front; SCKD - volcanoes of the Central Kamchatka Depression south of the Kamchatka River; NCKD - those north of the Kamchatka River; SR (IAB) - island-arc basalt type rocks of Sredinny Range; SR (WPT) - within-plate type rocks of Sredinny Range. Element concentrations are given in wt.\%. Classification lines for (A) after Le Maitre et al. [1989] and for (B) after Miashiro [1974]. FeO* - all iron expressed as FeO. 


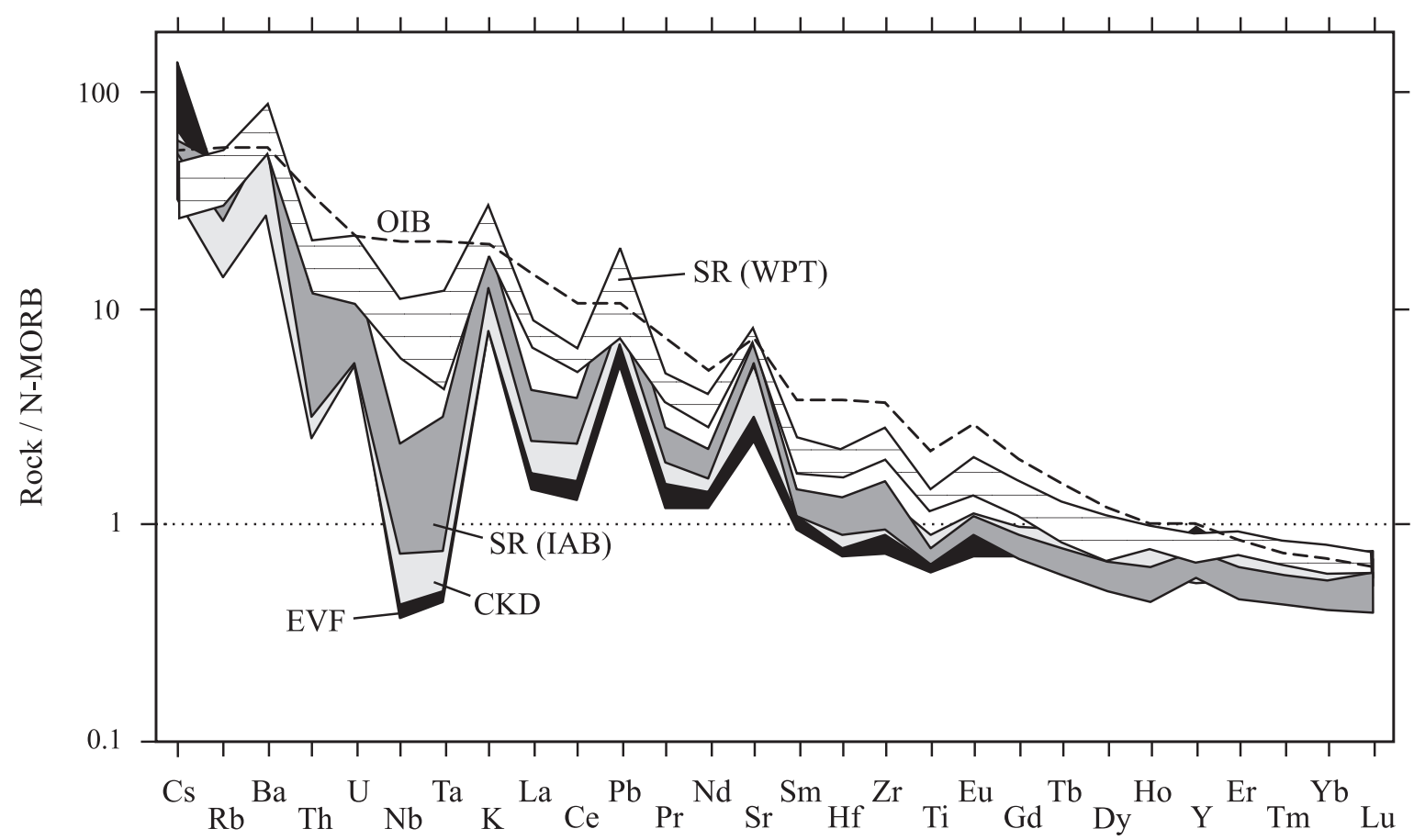

Figure 11. NMORB-normalized trace element patterns for mafic rocks of the different regions of Kamchatka. The order of incompatible elements is derived from Hofmann [1988] with Cs and all REE added. For clarity, each zone is expressed by a compositional field. SR (WPT) are significantly more enriched in all trace elements compared to all other lavas. Data from Churikova et al. [2001] and Volynets et al. [2005]. NMORB and OIB values after Sun and McDonough [1989].

the EVF to the CKD and a decrease from the CKD to the SR with strongest ${ }^{87} \mathrm{Sr}$-enrichment in CKD samples. Three trends could be distinguished on Figure 14, suggesting involvement of three different components. A component low in ${ }^{87} \mathrm{Sr} /{ }^{86} \mathrm{Sr}$ $(<0.7031)$ and high in ${ }^{143} \mathrm{Nd} /{ }^{144} \mathrm{Nd}(\sim 0.5131)$ is a MORB source within the mantle wedge. From the MORB field one array trends to higher Sr-isotope ratios with unchanged Nd-ratios. Slab fluids (or slab melts) are expected to have such composition. The second array tends to lower Nd-isotope ratios with a correlated increase in $\mathrm{Sr}$-isotopes. Such a trend probably results from mixing with an enriched mantle component and formed mainly by the SR back-arc rocks.

Using $\mathrm{Pb}$ isotopes data for the Kamchatka rocks and pelagic sediments from ocean drilling near Kamchatka, Kersting and Arculus [1995] argued that subducted sediments play a minor role in Kamchatka magma generation. These data were also confirmed by Be isotopes [Tsvetkov et al., 1989]. Recently, however, new data imply that subducted sediments/melts play a more important role in the genesis of the Kamchatka rocks [Duggen et al., 2007; Portnyagin et al., 2007a].

The degree of partial melting required for generation of the volcanic rocks of Kamchatka decreases from arc front to back arc. The rocks of the EVF display the highest source degree of melting of $14-20 \%$, the CKD and SR "normal" arc rocks show lower degrees of melting, down to 9-12\%, and samples with intraplate signatures in back arc show the lowest degree of melting at 7\% [Churikova et al., 2001; Portnyagin et al., 2007a].

On Th/Yb versus Ta/Yb diagram [Pearce, 1983] (Fig. 15), all samples from the EVF and NCKD and most samples from SCKD fall into the field of depleted mantle sources. However, the SR rocks form an array reaching from the oceanic arc towards an enriched mantle component. The existence of the enriched source was evidenced by the high-precision measurements of $\mathrm{Nb} / \mathrm{Ta}, \mathrm{Zr} / \mathrm{Hf}$, Lu/Hf ratios together with Hf isotopes [Münker et al., 2004].

Despite that, based on LREE and LILE concentrations, fluid contribution does not change across Kamchatka (Ce/ $\mathrm{Pb}, \mathrm{Ba} / \mathrm{Zr}$ ratios do not show systematic change) (Figs. 13B, F), elements more sensitive to arc fluid transport show strong cross-arc variations. Using volatile and fluid-mobile elements in melt inclusions from Kamchatka's olivines, different fluid compositions were found across Kamchatka. While fluid released in EVF and CKD carries high amounts of $\mathrm{B}, \mathrm{Cl}$ and $\mathrm{S}$ [Portnyagin et al., 2007a], the fluid below SR is enriched in Li and F (Fig. 16), [Churikova et al., 2004, 2007]. We argue that the dehydration of different water-rich minerals at different depths explains the difference in fluid 

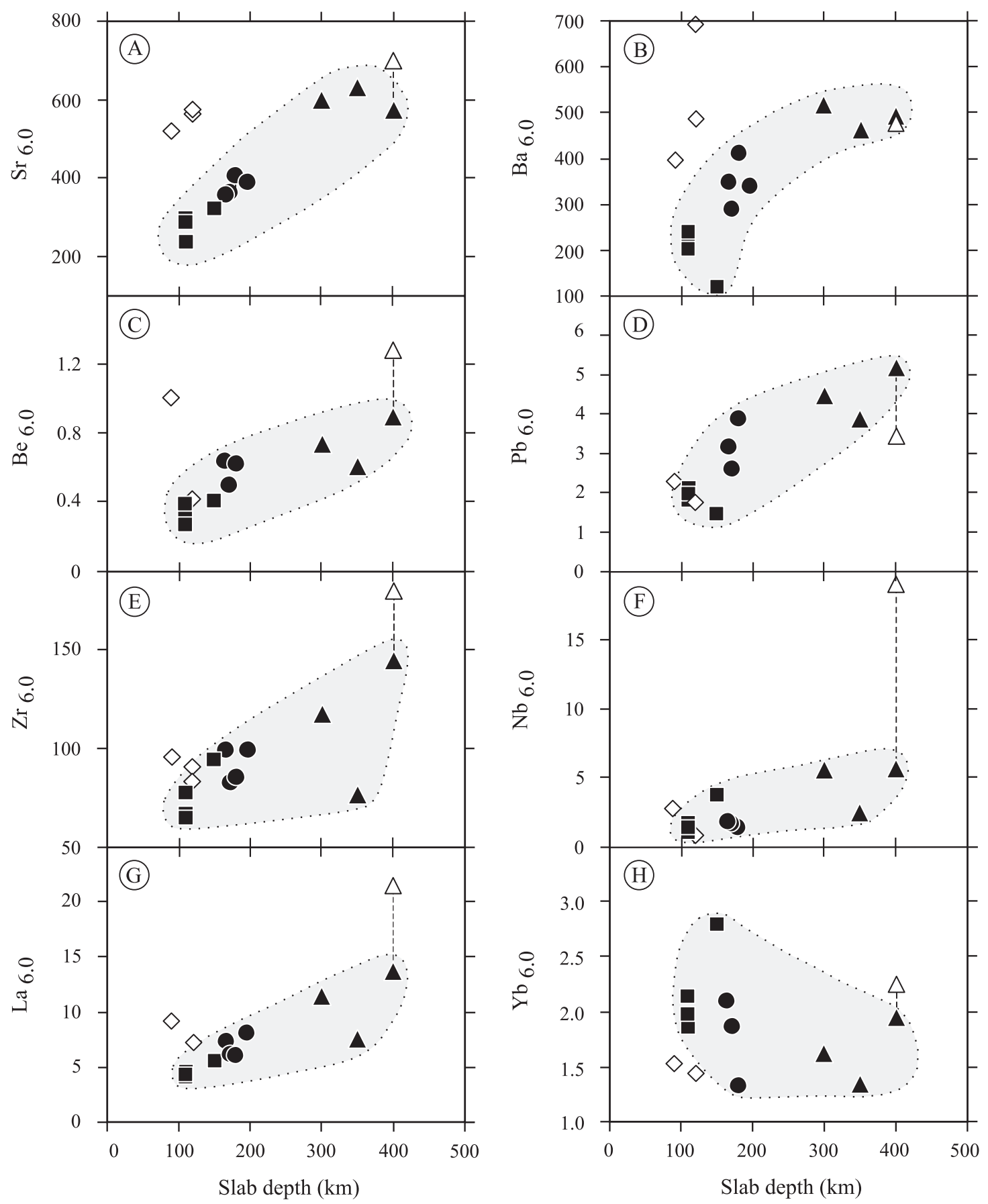

Figure 12. Fluid mobile trace element concentrations (A-D) and HFSE and REE concentrations (E-H) of single volcanoes in relation to the depth of the slab surface below the volcanoes for the northern Kamchatka transect. For correct comparison of differently fractionated volcanic series the data from each volcano were normalized to $6 \% \mathrm{MgO}$ following the approach used by [Plank and Langmuir, 1988]. The shaded fields were drawn to underline the trends of the typical arc magmas. The typical arc series of Ichinsky are connected by a dotted line with the WPT, occurring at the same volcano. Positive linear trends are well-defined for $\mathrm{Sr}_{60}, \mathrm{Ba}_{60}, \mathrm{Be}_{60}, \mathrm{~Pb}_{60}, \mathrm{Zr}_{60}, \mathrm{Nb}_{60}, \mathrm{La}_{60}$ and a week negative trend for $\mathrm{Yb}_{6.0}$ which are marked by shaded fields. However, the trends for HFSE and REE are less well defined than for the fluid mobile elements. Squares - EVF; circles - SCKD; diamonds - NCKD; triangles - SR. Element concentrations are given in ppm. Modified after Churikova et al. [2001]. 
composition across the Kamchatka arc and may significantly influence the chemical composition of the rocks.

Systematic geochemical variations from front-arc to back-arc argue for a single subduction zone. Trace element patterns seem to be mostly governed by slab fluid and variable source compositions in the mantle wedge. Rate of magma production by individual volcanoes depends on fluid flux, mantle wedge heterogeneity and the location of their magmatic sources with respect to the dehydrating slab.

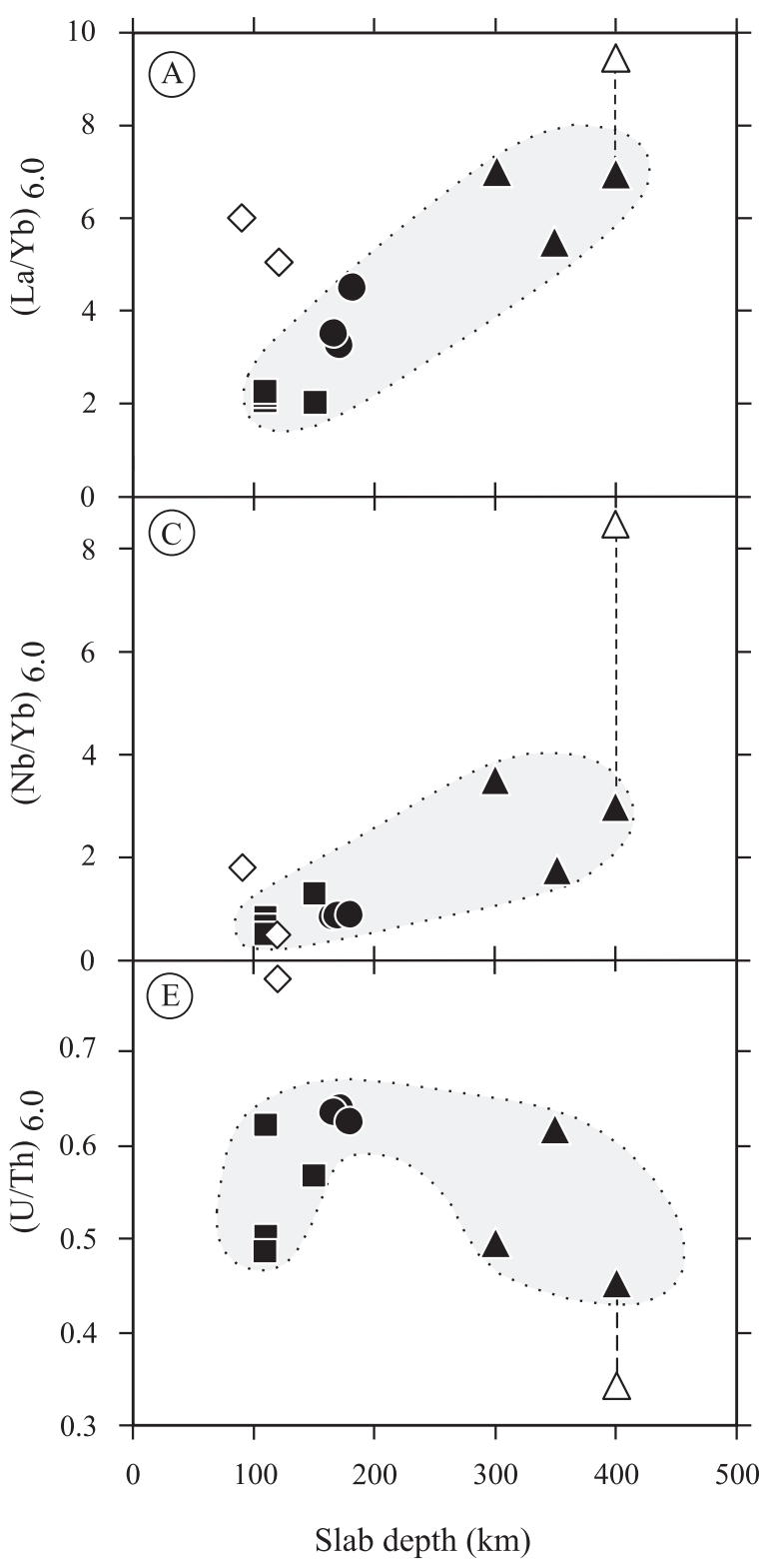

\section{Chemical Variations Along the Kamchatka arc}

No significant changes in chemical composition of the late Pleistocene-Holocene rocks have been found along EVF [Volynets, 1994] or northern part of SR (from Ichinsky to $\sim 50 \mathrm{~km}$ north of Titila) (Fig. 17A) [Volynets et al., 2005; Volynets, 2006]. In CKD, however, systematic changes in trace element ratios were observed from Kliuchevskoi group northwards to Nachikinsky and Khailulia volcanoes, that suggests a transition from fluid-induced melts through

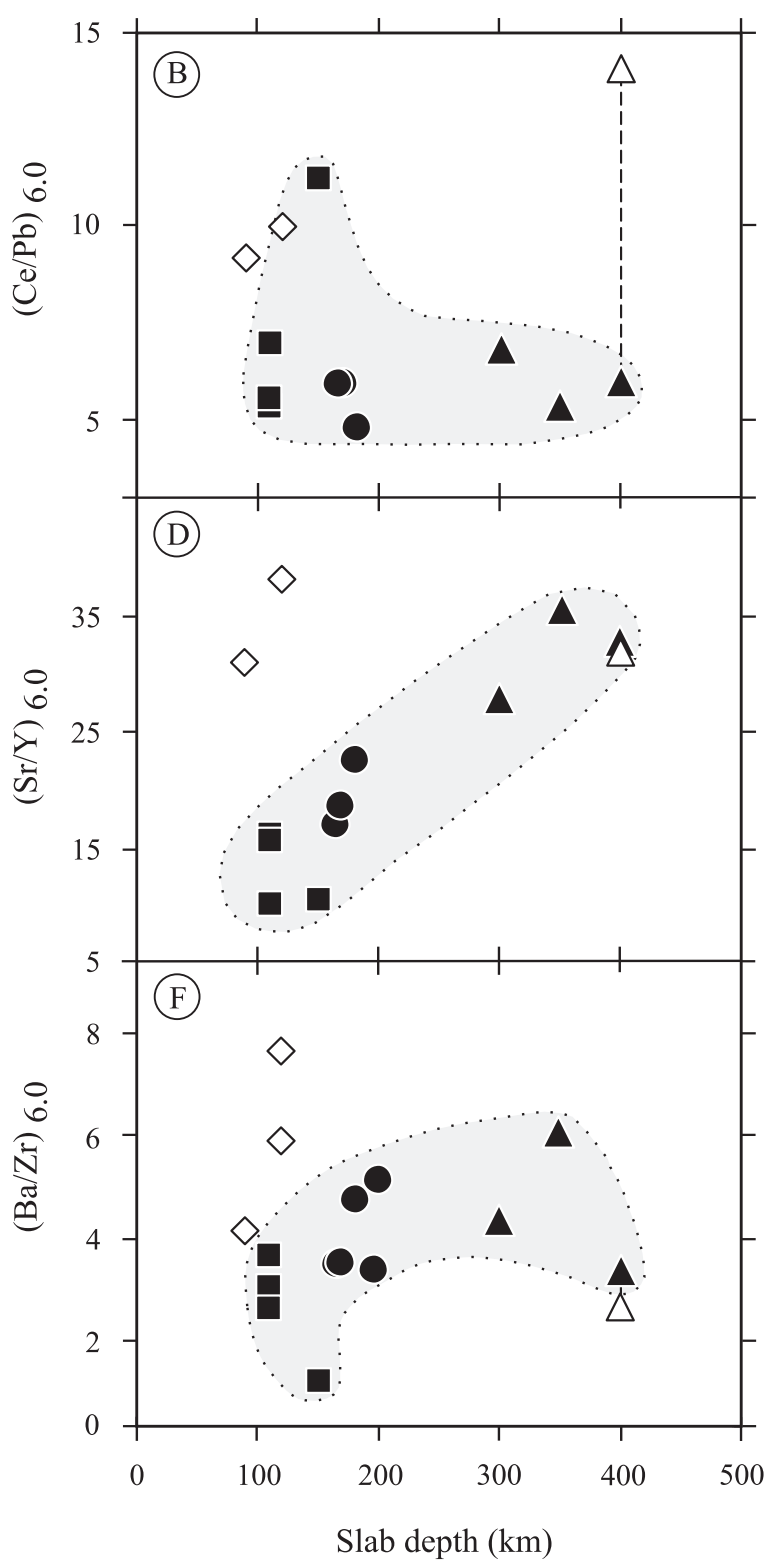

Figure 13. $6 \% \mathrm{MgO}$-normalized incompatible trace element ratios of single volcanoes in relation to the depth of the slab surface below the volcano. Positive linear trends exist for $(\mathrm{La} / \mathrm{Yb})_{6.0},(\mathrm{Nb} / \mathrm{Yb})_{6.0}$ and $(\mathrm{Sr} / \mathrm{Y})_{6.0}$. The $(\mathrm{Ce} / \mathrm{Pb})_{6.0},(\mathrm{Ba} / \mathrm{Zr})_{6.0}$ and $(\mathrm{U} / \mathrm{Th})_{6.0}$ ratios do not show regular trends. Symbols as in Fig. 12. Modified after Churikova et al. [2001]. 


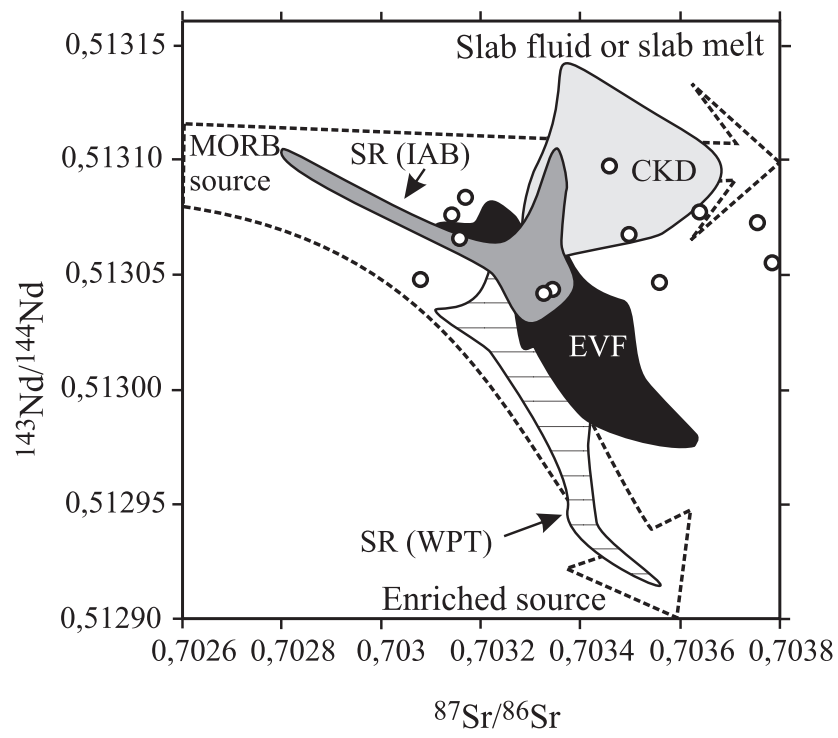

slab-influenced source to intra-plate melt compositions (Fig. 17B), [Portnyagin et al., 2005]. Khailulia and most of Nachikinsky, however, likely started to form in earlymid-Pleistocene times, so they are significantly older than
Figure 14. ${ }^{143} \mathrm{Nd} /{ }^{144} \mathrm{Nd} \mathrm{vs}{ }^{87} \mathrm{Sr} /{ }^{86} \mathrm{Sr}$ for Kamchatka rocks. Data from Churikova et al [2001]; Dorendorf et al. [2000a, b] and Volynets [2006]. The points of leached clinopyroxene from mantle xenoliths for Kamchatka [Dorendorf, 1998; Koloskov, 1999] are marked by white circles and shows for Nd-isotopes a comparable and for Srisotopes an even larger range than observed in the volcanic rocks. Arrows are drawn schematically to show three-component mixing between slab fluid, MORB and enriched mantle source. SR rocks show mixing line between MORB and OIB sources.

the late Pleistocene-Holocene Tolbachik, Kliuchevskoi and Shiveluch. These changes might reflect variations of melts both in space and time.

\section{CKD Volcanoes}

The best studied volcanoes in Kamchatka are in CKD, with the Kliuchevskoi group south of the Kamchatka River (SCKD) and the NCKD group with Shiveluch, Zarechny and Kharchinsky volcanoes north of the river (Fig. 4) [e.g. Ozerov, 2000; Khubunaya et al., 1995, Volynets et al., 1999b; Dorendorf et al., 2000a, Kersting and Arculus, 1994; Mironov et al., 2001; Portnyagin et al., 2005, 2007a, b]. The reason for CKD's high volcanic activity could be related to intra-arc

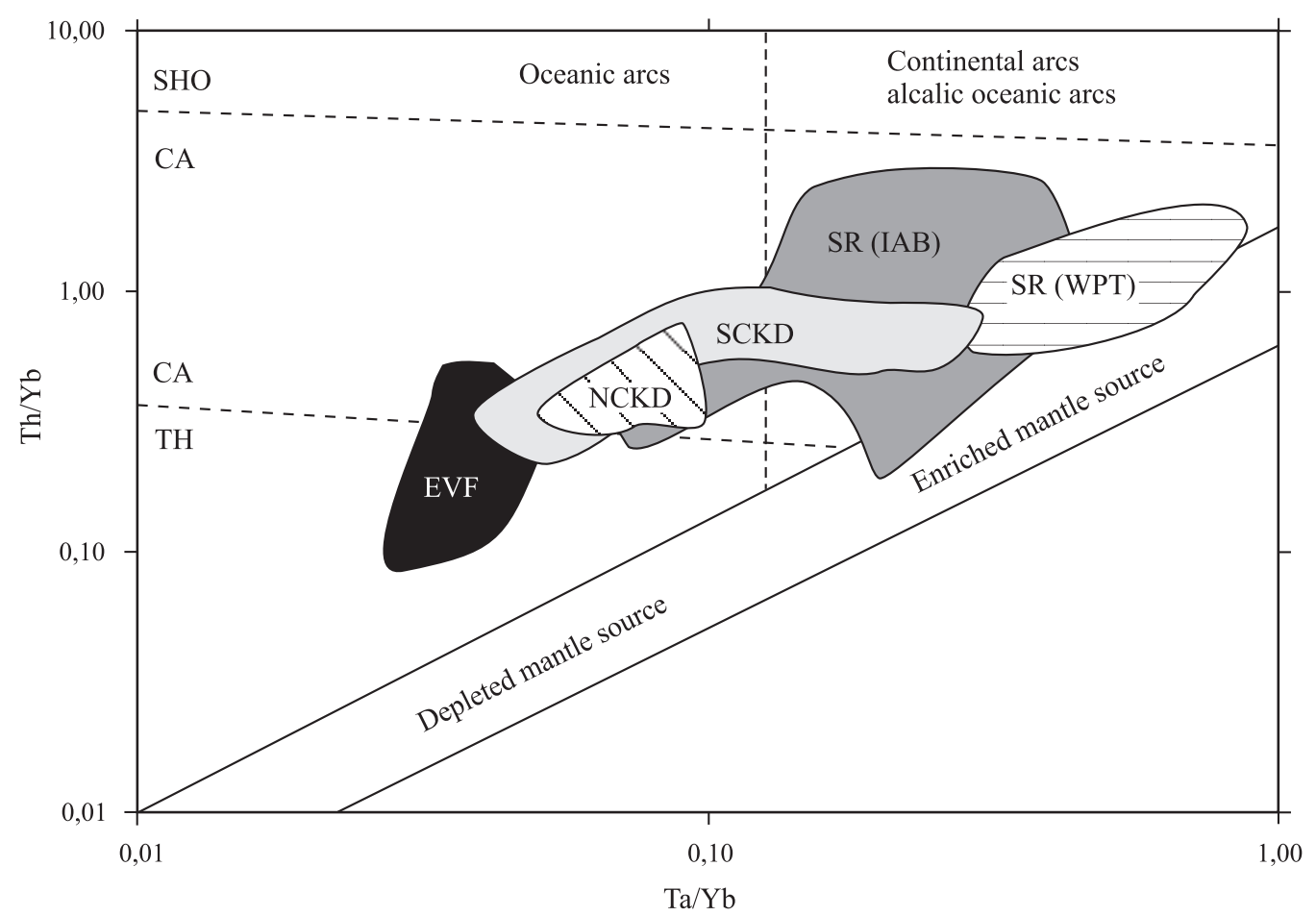

Figure 15. Th/Yb vs. Ta/Yb after Pearce [1983]. Nearly all samples from EVF and SCKD as well as most NCKD samples fall into the field of oceanic arcs formed from depleted mantle sources. In a contrast, the SR samples trend towards an enriched mantle composition (shaded field). SHO - shoshonitic series; CA - calc-alkaline series; TH - tholeiitic series. Data from Churikova et al [2001]; Dorendorf et al. [2000b], Ivanov et al. [2004], and Volynets et al. [2005]. 
rifting and upwelling in this area. Yogodzinski et al. [2001a] suggested that mantle wedge below CKD is extraordinary hot because of a hot mantle flow around the edge of the subducting Pacific plate. Even if the degree of melting is not very high (around 12\%), a large volume of mantle could be involved in this melting due to massive decompression below the rift. CKD rocks are enriched in ${ }^{87} \mathrm{Sr}$, and elevated $\mathrm{U} / \mathrm{Th}$ and $\mathrm{Ba} / \mathrm{Zr}$ ratios (Figs. 14 and 16), [e.g. Churikova and Sokolov, 1993, Dorendorf et al., 2000a, Wörner et al., 2001]. We conclude that the high magma production rate in CKD may be caused by: (1) intra-arc rifting, following upwelling and enhanced decompression melting and (2) enhanced fluid-flux from the Emperor Seamounts Chain.

Most of SCKD rocks are medium-K calc-alkaline basaltandesite series (Fig. 10). At the same time, on Plosky Tolbachik volcano and Plosky massif high-K tholeiitic rocks occur along with "normal" medium-K calc-alkaline volcanic rocks. High-K rocks are enriched in all incompatible elements, but exhibit low HFSE, and therefore fall off the across-arc trend for most geochemical parameters. Despite the fact that such rocks were found only on a few volcanoes, they have significant volumes and so merit further detailed examination. For example, in the Tolbachik lava field, individual eruptions produced up to $1-2 \mathrm{~km}^{3}$ of high-K basalt and the total for the Holocene rocks of this composition approaches to $70 \mathrm{~km}^{3}$ [Braitseva et al., 1984; Flerov et al., 1984].

NCKD volcanoes (Shiveluch, Zarechny, Kharchinsky) display trace element patterns distinct from the SCKD
[Yogodzinski et al., 2001a; Portnyagin et al., 2005]. They have high $\mathrm{Sr} / \mathrm{Y}$ ratios of $\sim 35$ and La/Yb of $\sim 5$ (Figs. 10, 12, 13), which by far exceed compositions on the across-arc trend (Figs. 10B, 12, 13, 17). Such a pattern is typical for adakites, for which an origin from slab melting is assumed [Defant and Drummond, 1990]. The adakite-type signatures were explained by tearing of the slab and warming of the slab edge by hot asthenospheric mantle [Volynets et al., 1997b; Yogodzinski et al., 2001a].

\section{Other Rock Types}

Rare rock types occur locally and include shoshonitelatite series [Volynets, 1994], avachite (high-Mg basalt found near Avachinsky volcano), allivalites (Ol-Pl highly crystallized rocks which occur mostly as inclusions in low$\mathrm{K}$ mafic and silicic tephras), high-K high-Mg phlogopitebearing and hornblende-bearing basalt-basaltic andesite found only in one tephra from Shiveluch volcano [Volynets et al., 1997a], etc.

Unlike most other arcs, Kamchatka rocks are rich in mantle-derived xenoliths (mostly dunites, harzburgites, and clinopyroxenites, with fewer wehrlites) [Koloskov, 1999; Bryant et al., 2005; Dektor et al., 2005] that provide an opportunity to directly observe mantle material altered by subduction processes. Trace elements indicate that Kamchatka xenoliths are depleted in $\mathrm{Nb}$ and Ta relative to Ba and light REEs [Turner et al., 1998; Yogodzinski et al., 2001b].

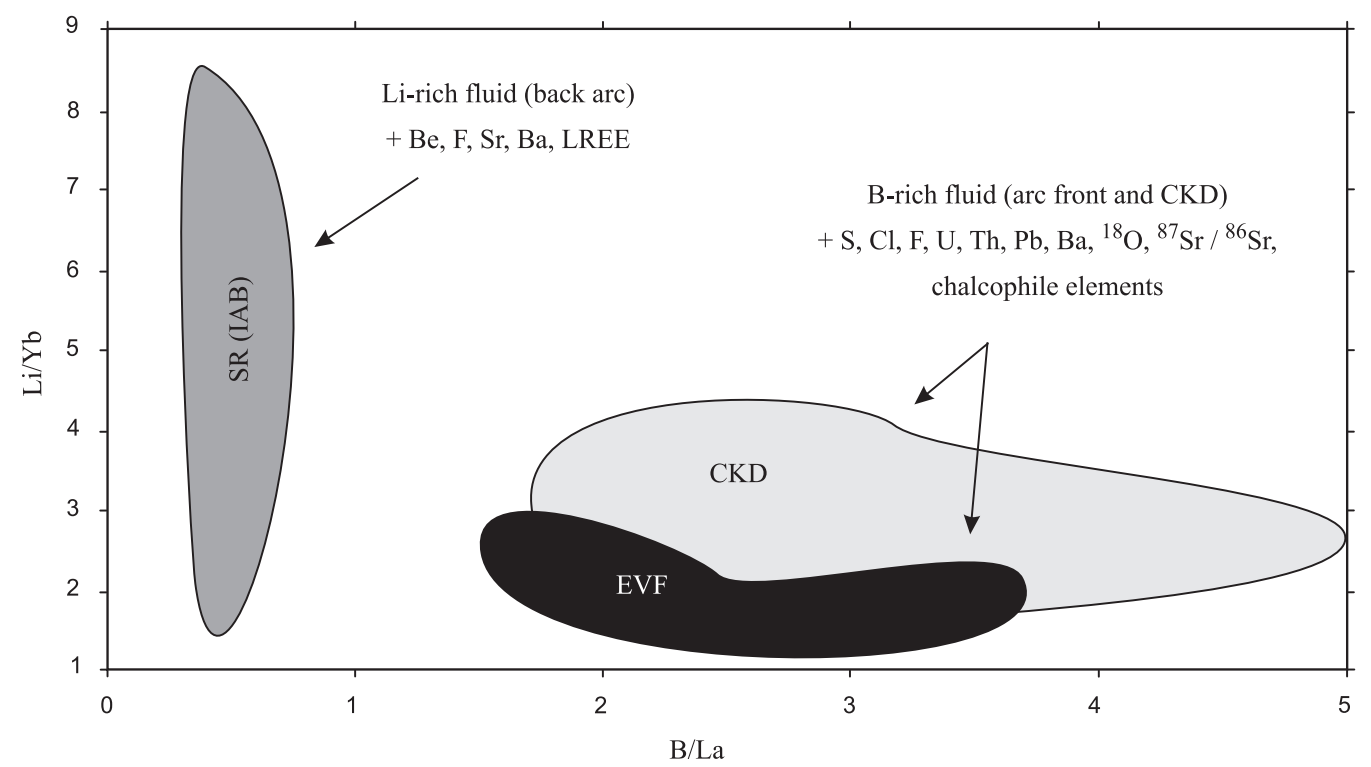

Figure 16. B-Li systematics in melt inclusions from olivines from rocks across the Kamchatka arc, showing the decoupling of $\mathrm{B}$ and $\mathrm{Li}$. This results in high $\mathrm{B} / \mathrm{La}$ in arc front magmas and a strong increase in $\mathrm{Li} / \mathrm{Yb}$ towards the back arc. Field as in Figure 10. 

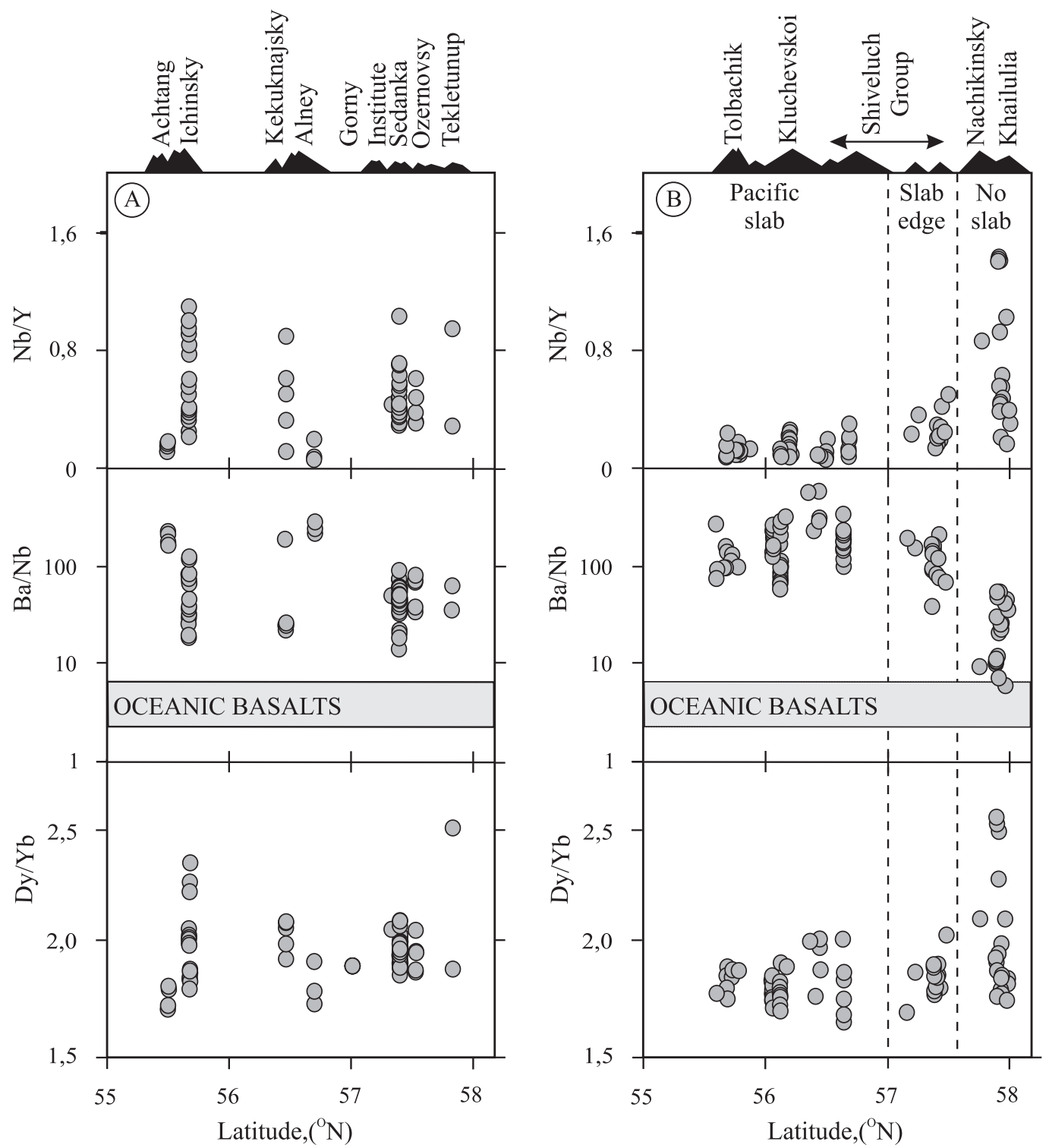

Figure 17. Along-arc variations of trace element ratios in SR (A) and CKD (B) lavas. No systematic changes have been found along the Sredinny Range (A) while the CKD lavas show a transition from fluid-induced melts over Pacific slab through slab-influenced magmas above the slab edge to intra-plate compositions farther north (B). The range of $\mathrm{Ba} / \mathrm{Nb}$ for oceanic basalts (MORB and OIB) is shown after Sun and McDonough [1989]; the range of Nb/Y and Dy/Yb for oceanic basalts covers the entire range shown in diagrams. Data sources: (A) - Volynets [2006]; (B) - modified after Portnyagin et al. [2005].

\section{CONCLUSION: FUTURE TASKS}

Changes in the spatial-temporal patterns of volcanism and composition of volcanic rocks reflect large-scale tectonic processes. Further steps in understanding Quaternary volcanism in Kamchatka should, in our opinion, combine radiometric dating of the volcanic rocks with studies of their geochemical affinities. In addition to across-arc variations in rock composition, more along-arc traverses should be studied. Special attention must be paid to northern Kamchatka, where volcanism seemingly extends beyond an active subduction zone (Fig. 2B).

Even in the best studied Kliuchevskoi group, some volcanoes like Udina or Zimina (southeastern part of the group, (Fig. 4) were last visited in 1970-ies and their rocks have never been analyzed in detail. The Kliuchevskoi volcanic group has been recording tectonic processes in the Kamchatka-Aleutian 
"corner" or triple junction (Fig. 2B) starting from at least midPleistocene, so changes in production rates and compositions of its rocks, once reconstructed, can shed light on the evolution of this structure.

Similar efforts should be made in the studies of the pre-late Pleistocene volcanism including voluminous late Pliocene-Early Pleistocene lava plateaus in Sredinny Range and spectacular shield volcanoes. Of special interest are volcanic fields that existed during only one period and did not resume their activity later (Fig. 2B) (e.g. lava field NE of Shiveluch and fields in the northernmost part of the peninsula). These volcanic deposits likely record major events in the plate history of the region.

At the Holocene scale, attempts of correlating paleovolcanic and paleoseismic records [Bourgeois et al., 2006; Kozhurin et al., 2006; Pinegina et al., 2003] and identifying periods of overall high tectonic activity and natural catastrophes [Melekestsev et al., 1998, 2003a,b] are most intriguing. Near their sources, both volcanic and seismic events can produce marked changes in the landscape, building volcanoes, triggering large debris flows and floods, producing conspicuous ground deformation, and reorienting river drainages. At a distance, large earthquakes and volcanic eruptions also leave their mark, causing tsunamis, heavy ash falls, and atmospheric pollution. Major subduction-zone events may include many of these proximal and distal components, which combine their effects and cause more serious and variable consequences than anticipated for individual volcanic or seismic events alone. Studies of such recent geological catastrophes in Kamchatka, based on distal correlations of various deposits with the help of marker tephra layers, hopefully will help to understand the space-time patterns of catastrophic events, make long-term forecasts of future episodes, and to model potential natural catastrophes around the Pacific Rim.

Acknowledgements. The research was supported by grants \#\# 05-05-64776, 06-05-64960 and 06-05-65037 from the Russian Foundation for Basic Research; by the Russian Academy of Sciences Program "Environmental and Climate Change"; by the Russian Ministry of Industry and Science projects \#43.700.11.0005, 43.043.11.1606 and State Contract with Federal Agency of Science and Innovations' Department of Survey and New Technologies Development \#01.700.12.0028 to Tatiana Churikova and NSF grant \#EAR-0125787 to Joanne Bourgeois. Geochemical studies would not be possible without continuous support and attention from Gerhard Wörner to whom the authors are most grateful. The field work in 1996-2000, 2002, and 2004 was supported by the grants from the National Geographic Society to Vera Ponomareva. We thank John Eichelberger for editing the first version of this manuscript. We appreciate the help from Gene Yogodzinski and an anonymous reviewer, whose comments and suggestions have allowed us to improve the manuscript.

\section{REFERENCES}

Ananiev, V. V., N. A. Titaeva, and A. N. Troshin (1980), Uran-Ionium and track dating of the volcanic rocks, in $A$ volcanic center: structure, dynamics and substance of the Karymsky center, edited by Masurenkov Yu. P., pp. 199-235, Nauka, Moscow, (in Russian)

Avdeiko, G.P., S.V. Popruzhenko, and A.A. Palueva (2002), The tectonic evolution and volcano-tectonic zonation of the KurilKamchatka island-arc system, Geotectonics, 36(4), 312-327.

Avdeiko G. P., Palueva A.A., and O. A. Khleborodova (2006), Geodynamic conditions of volcanism and magma formation in the Kurile-Kamchatka island-arc system, Petrology, 14 (3), 230-246.

Bazanova, L. I., O. A. Braitseva, M. Yu. Puzankov, and L. D. Sulerzhitsky (2003), Catastrophic plinian eruptions of the initial cone-building stage of the Young Cone of Avachinsky volcano (Kamchatka), Volcanol. and Seismol., (6), 20-40 (In Russian).

Bazanova, L. I., and M. M. Pevzner (2001), Khangar: One more active volcano in Kamchatka, Transactions (Doklady) of the Russian Academy of Sciences, Earth Sciences, 377A, 307-310.

Bazanova, L. I., O. A. Braitseva, I. V. Melekestsev, and M. Yu. Puzankov (2001), Expected hazard from the Avachinsky volcano eruptions, in Geodynamics and volcanism of the Kurile-Kamchatka island arc system. Petropavlovsk-Kamchatsky. 390-407, (In Russian).

Bazanova, L. I., O. A. Braitseva, I. V. Melekestsev, and L. D. Sulerzhitsky (2004), Catastrophic eruptions of Avachinsky volcano (Kamchatka) in Holocene: chronology, dynamics, geological effect, environmental impact and long-term forecast. Volcanol. and Seismol., (6), 15-20, (In Russian).

Bazanova, L. I., O. A. Braitseva, O.V. Dirksen, L. D. Sulerzhitsky, and T.Danhara (2005) Ashfalls from the largest Holocene eruptions along the Ust'-Bol'sheretsk - Petropavlovsk-Kamchatsky traverse: sources, chronology, recurrence. Volcanol. and Seismol., (6), 30-46, (In Russian).

Bindeman, I. N., and J. C. Bailey (1994), A model of reverse differentiation at Dikii Greben' volcano, Kamchatka: progressive basic magma vesiculation in a silicic magma chamber, Contrib. Mineral. Petrol., 117, 263-278.

Bindeman, I. N., V. V. Ponomareva, J. C. Bailey, and J.W. Valley (2004), Kamchatka Peninsula: a province with high- $\delta^{18} \mathrm{O}$ magma sources and large ${ }^{18} \mathrm{O} /{ }^{16} \mathrm{O}$ depletion of the upper crust, Geochimica et Cosmochimica Acta, 68(4), 841-865.

Bourgeois J., T. K. Pinegina, V.V. Ponomareva, and N.E. Zaretskaia (2006), Holocene tsunamis in the southwestern Bering Sea, Russian Far East and their tectonic implications, The Geol. Soc. Amer. Bull., 11(3/4), 449-463; doi: 10.1130/B25726.1.

Braitseva, O. A., I.V. Melekestsev, and E.N. Erlikh (1974), Recent volcanic activity, in Kamchatka, Kurile and Commander Islands, edited by I. V. Luchitsky, Nauka, Moscow, pp. 369-394, (in Russian).

Braitseva, O. A., I. A. Egorova, L. D. Sulerzhitsky, and I. A. Nesmachny (1980), Maly Semiachik volcano, in A volcanic center: structure, dynamics and substance of the Karymsky center, 
edited by Yu. P. Masurenkov, Nauka, Moscow, pp. 199-235, (In Russian).

Braitseva, O. A., I. V. Melekestsev, G. B. Flerov, V. V. Ponomareva, L. D. Sulerzhitsky, and S. N. Litasova (1984), Holocene volcanism of the Tolbachik regional zone of cinder cones, in Great Tolbachik Fissure Eruption, Kamchatka, 1975-1976, edited by S. A. Fedotov, Nauka, Moscow, pp. 177-222, (In Russian).

Braitseva, O. A., S. N. Litasova, and A. K. Ponomarenko (1987), Application of tephrochronology for dating a key archaeological site in Eastern Kamchatka, Volcanol. and Seismol., 5(5), 507-514.

Braitseva, O. A., I. V. Florenskii, V. V. Ponomareva, and S. N. Litasova (1989), The history of the activity of Kikhpinych volcano in the Holocene, Volcanol. and Seismol., 7(6), 845-872.

Braitseva, O. A., and I. V. Melekestsev (1990), Eruptive history of Karymsky volcano, Kamchatka, USSR, based on tephra stratigraphy and ${ }^{14} \mathrm{C}$ dating, Bul.l Volcanol., 53, 195-206.

Braitseva, O. A., I. V. Melekestsev, G. E. Bogoyavlenskaya, and A. P. Maksimov (1991), Bezymianny volcano: eruptive history and activity dynamics, Volcanol. and Seismol., 12(2), 165-194.

Braitseva, O. A., L. D. Sulerzhitsky, S. N. Litasova, I. V. Melekestsev, and V. V. Ponomareva (1993), Radiocarbon dating and tephrochronology in Kamchatka, Radiocarbon, 35(3), 463-476.

Braitseva, O. A., I. V. Melekestsev, V. V. Ponomareva, and L. D. Sulerzhitsky (1995), The ages of calderas, large explosive craters and active volcanoes in the Kuril-Kamchatka region, Russia, Bull. of Volcanology, 57(6), 383-402.

Braitseva, O. A., I. V. Melekestsev, V. V. Ponomareva, and V. Yu. Kirianov (1996), The caldera-forming eruption of Ksudach volcano about cal. AD 240, the greatest explosive event of our era in Kamchatka, J. Volcanol. Geotherm. Res., 70(1-2), 49-66.

Braitseva, O. A., L. D. Sulerzhitsky, V. V. Ponomareva, and I. V. Melekestsev (1997a), Geochronology of the greatest Holocene explosive eruptions in Kamchatka and their imprint on the Greenland glacier shield, Trans. Russian. Acad. Sci., 352(1), $138-140$.

Braitseva, O. A., V. V. Ponomareva, L. D. Sulerzhitsky, I. V. Melekestsev, and J. Bailey (1997b), Holocene key-marker tephra layers in Kamchatka, Russia, Quaternary Res., 47(2), 125-139.

Braitseva, O. A., L. I. Bazanova, I. V. Melekestsev, and L. D. Sulerzhitsky (1998), Largest Holocene eruptions of Avachinsky volcano, Kamchatka, Volcanol. and Seismol., 20, 1-27.

Braitseva, O. A., I. V. Melekestsev, and L. D. Sulerzhitsky (2005), New data on the Pleistocene deposits in the Central Kamchatka Depression, Stratigraphy and Geological correlation, 13(1), 99-107.

Bryant, J. A., G. M. Yogodzinski, and T. G. Churikova (2005), Petrology of metasomatised mantle xenoliths from Shiveluch Volcano, Kamchatka, Goldschmidt Conference Abstracts. Subduction Zone Magmatism, A642.

Calkins, J. (2004), ${ }^{40} \mathrm{Ar} /{ }^{39} \mathrm{Ar}$ geochronology of Khapitsa Plateau and Studyonaya River basalts and basaltic andesites in Central Kamchatka Depression, Kamchatka, Russia, Abstracts IV JKASP International workshop.
Cambray, H., and J.-P. Cadet (1996), Synchronisme de l'activite volcanique d'arc: Mythe ou realite?, C. R. Acad. Sci. Paris, 322, 237-244.

Cao, L. Q., R. J. Arculus, and B. C. McKelvey (1995), Geochemistry and petrology of volcanic ashes recovered from Sites 881 through 884: A temporal record of Kamchatka and Kurile volcanism, in Proceedings of the Ocean Drilling Project, Scientific Results, 145 , edited by D. K. Rea et al., College Station, Texas, Ocean Drilling Program, pp. 345-381.

Churikova, T. G., and S. Yu. Sokolov (1993), The magmatic evolution of Ploskie Sopky volcano, Kamchatka (analyses of $\mathrm{Sr}$ isotopic geochemistry), Geochemistry, 10, 1439-1448.

Churikova, T., F. Dorendorf, and G. Wörner (2001), Sources and fluids in the mantle wedge below Kamchatka, evidence from across-arc geochemical variation, J. Petrol., 42(8), 1567-1593.

Churikova, T., G. Wörner, N. Mironov, A. Kronz, P. Pletchov, and M. Portnyagin (2004), Halogens and Sulfur Across the Kamchatka Arc, AGU Fall Meeting, EOS, (7), F540.

Churikova, T., G. Wörner, N. Mironov, and A. Kronz (2007), Volatile $(\mathrm{S}, \mathrm{Cl}$ and $\mathrm{F})$ and fluid mobile trace element compositions in melt inclusions: Implications for variable fluid sources across the Kamchatka arc, Contributions to Mineralogy and Petrology, in press, DOI 10.1007/s00410-007-0190-z.

Defant, M. J., and M. S. Drummond (1990), Derivation of some modern arc magmas by melting of young subducted lithosphere, Nature (London), 347, 662-665.

Dektor, C. L., G. M. Yogodzinski, and T. G. Churikova (2005), Petrology of ultramafic xenoliths from Kharchinsky Volcano, Russia, Goldschmidt Conference Abstracts. Subduction Zone Magmatism, A643.

DeMets, C. (1992), Oblique convergence and deformation along the Kuril and Japan trenches, J. Geophys. Res., 97, 17615-17625.

Dirksen, O. V., and I. V. Melekestsev (1999), Chronology, evolution and morphology of plateau basalt eruptive centers in Avacha River area, Kamchatka, Russia, Volcanol and Seismol., 21(1), $1-28$.

Dirksen, O. V., V.V. Ponomareva, and L. D. Sulerzhitsky (2002), Eruption from Chasha Crater - a unique large silicic eruption at a monogenetic basaltic lava field, Volcanol. and Seismol., (5), 3-10, (In Russian).

Dirksen, O. V., L. I. Bazanova, and M. Portnyagin (2003), Chronology of the volcanic activity in the northern part of Sredinny Range (Sedanka lava field) in the Holocene, in Volcanism and geodynamics, Materials of the II Russian symposium on volcanology and paleovolcanology, Ekaterinburg, 871-874.

Dirksen, V. (2004), Holocene Vegetation Changes in Eastern Kamchatka Based on Pollen and Macrofossil Records, Eos Trans. $A G U$, 85(47), Fall Meet. Suppl., Abstract PP21B-1378.

Dorendorf, F. (1998), Genesis of Quaternary volcanic rocks from Kamchatka, Russia, Ph. D. Thesis, Geochemishes Institute, Göttingen University, Germany.

Dorendorf, F., U. Wiechert, and G. Wörner (2000a), Hydrated sub-arc mantle: a source for Kluchevskoy volcano / Kamchatka, Earth Planet. Sci. Lett., 175, 69-86. 
Dorendorf, F., T. Churikova, A. Koloskov, and G. Wörner (2000b), Late Pleistocene to Holocene activity at Bakening volcano and surrounding monogenetic centers (Kamchatka): volcanic geology and geochemical evolution, J. of Volcanology and Geothermal Research. 104, 131-151.

Duggen, S., Portnyagin, M., Baker, J., Ulfbeck, D., Hoernle, K., Garbe-Schönberg, D., and N. Grassineau (2007), Drastic shift in lava geochemistry in the volcanic-front to rear-arc region of the Southern Kamchatkan subduction zone: Evidence for the transition from slab surface dehydration to sediment melting, Geochimica et Cosmochimica Acta, 71(2), 452-480.

Eichelberger, J. C., and P. Izbekov (2000), Eruption of andesite triggered by dyke injection: contrasting cases at Karymsky volcano, Kamchatka and Mount Katmai, Alaska, Royal Soc. London Phil. Trans., ser. A, 358, 1465-1485.

England, P., R. Engdahl, and W. Thatcher (2004), Systematic variation in the depths of slabs beneath arc volcanoes, Geophys. J. Int., 156, 377-408.

Erlich, E. N., I.V. Melekestsev, and O.A. Braitseva (1979), Evolution of Recent Volcanism, in Quaternary Volcanism and Tectonics in Kamchatka, edited by E. N. Erlich and G. S. Gorshkov, Bull. Volcanol., 42, 93-112.

Erlich, E. (1986), Geology of the calderas of Kamchatka and Kurile Islands with comparison to calderas of Japan and the Aleutians, Alaska, U. S. Geol. Surv. Open-File Report. 86-291. 300 p.

Fedotov, S. A., and Yu. P. Masurenkov (eds) (1991), Active volcanoes of Kamchatka, Vol.1, 302 p., Vol.2, 415 p., Nauka, Moscow.

Flerov G.B., V.N.Andreev, V.A.Budnikov, and A.I.Tsyurupa (1984), Petrology of the erupted products, in Great Tolbachik Fissure Eruption, Kamchatka, 1975-1976, edited by S. A. Fedotov, Nauka, Moscow, pp. 223-284, (In Russian).

Florensky, I.V. (1984), On the age of Uzon and Krasheninnikov calderas, Volcanol. and Seismol., (1), 102-105, (In Russian).

Florensky I. V. and V. G. Trifonov (1985), Neotectonics and volcanism in the East Kamchatka volcanic zone, Geotektonika, (4), 78-87 (In Russian).

Gorbatov, A., V. Kostoglodov, G. Suarez, and E. I. Gordeev (1997), Seismicity and structure of the Kamchatka subduction zone, $J$. Geophys. Res., B, 102(8), 17,883-17,898.

Gusev, A. A., V. V. Ponomareva, O. A. Braitseva, I. V. Melekestsev, and L. D. Sulerzhitsky (2003), Great explosive eruptions on Kamchatka during the last 10,000 years: self-similar irregularity of the output of volcanic products, J. Geophys. Res., 108(B2), 2126, doi: 10.1029/2001JB000312.

Hildreth, W. (1983), The compositionally zoned eruption of 1912 in the Valley of Ten Thousand Smokes, Katmai National Park, Alaska, Journal of Volcanology and Geothermal Research, 18(1-4), 1-56.

Ho, C. H., E. I. Smith, D. L. Feuerbach, and T. R. Naumann (1991), Eruptive probability calculation for the Yucca Mountain site, USA: statistical estimation of recurrence rates, Bull. Volcanol., $54,50-56$.

Hofmann, A. W. (1988), Chemical differentiation of the Earth; the relationship between mantle, continental crust, and oceanic crust, in Isotope geochemistry; the Crafoord symposium. Earth and Planetary Science Letters, edited by E. Welin, Amsterdam, Elsevier, pp. 297-314.

Holocene volcanoes in Kamchatka, http://www.kscnet.ru/ivs/volcanoes/holocene

Ivanov, B.V. (1990), Types of the andesite volcanism within the Pacific volcanic belts, 213 p., Nauka, Moscow (In Russian).

Ivanov, A.V., A.B. Perepelov, M.Yu. Puzankov, T.A. Yasnygina1, Yu.M. Malykh1, and S.V. Rasskazov (2004), Rift- and arc-type basaltic volcanism of the Sredinny Ridge, Kamchatka: case study of the Payalpan volcano-tectonic structure. Metallogeny of the Pacific Northwest: Tectonics, Magmatism and Metallogeny of Active Continental Margins (Khanchuk, A.I. et al. Eds) Dalnauka, Vladivostok, 345-349 (In Russian).

Jones, G., D. K. Chester, and F. Shooshtarian (1999), Statistical analyses of the frequency of eruptions at Furnas Volcano, Sao Miguel, Azores, J. Volcanol. Geotherm. Res., 92, 31-38.

Kadik, A.A., A.P. Maksimov, and B.V. Ivanov (1986), PhysicoChemical Conditions of Crystallization and Genesis of Andesites, 158 p., Nauka, Moscow (In Russian).

Kennett, J. P., A. R. McBirney, and R. C. Thunell (1977), Episodes of Cenozoic volcanism in the circum-Pacific region, J. Volcanol. Geotherm. Res., 2, 145-163.

Kepezhinskas, P., F. McDermott, M. J. Defant, A. Hochstaedter, M. S. Drummond, C. J. Hawkesworth, A. Koloskov, R. C. Maury, and H. Bellon (1997), Trace element and $\mathrm{Sr}-\mathrm{Nd}-\mathrm{Pb}$ isotopic constraints on a three-component model of Kamchatka Arc petrogenesis, Geochimica et Cosmochimica Acta, 61, 577-600.

Kersting, A. B., and R. J. Arculus (1994), Kliuchevskoi volcano, Kamchatka, Russia - the role of high-flux recharged, tapped, and fractionated magma chamber(s) in the genesis of high- $\mathrm{Al}_{2} \mathrm{O}_{3}$ from high-MgO basalt, J. of Petrology, 35(1), 1-42.

Kersting, A. B., and R. J. Arculus (1995), Pb systematics of Kliuchevskoi volcano, Kamchatka, and North Pacific sediments: Implications for magma genesis and sediment recycling in the Kamchatka arc, Earth Planet Sci. Lett., 136, 133-148.

Khubunaya, S. A., N. A. Zharinov, Ya. D. Muravyev, V. V. Ivanov, G. E. Bogoyavlenskaya, T. Yu. Novgorodtseva, Yu. V. Demyanchuk, V. A. Budnikov, and S. M. Fazlullin (1995), 1993 eruption of Shiveluch volcano, Volcanol. and Seismol., 17, 1-20.

Koloskov A.V. (1999), Ultramafic inclusions and volcanic rocks as self-adjusted geological system, 224 p., Nauchnij Mir, Moscow (In Russian).

Kozhurin, A. I. (2004), Active faulting at the Eurasian, North American and Pacific plates junction, Tectonophysics, 380, 273-285.

Kozhurin, A., V. Acocella, P. R. Kyle, F. M. Lagmay, I. V. Melekestsev, V. Ponomareva, D. Rust, A. Tibaldi, A. Tunesi, C. Corazzato, A. Rovida, A. Sakharov, A. Tengonciang, and H. Uy (2006), Trenching active faults in Kamchatka, Russia: paleoseismological and tectonic implications, Tectonophysics, 417, 285-304.

Lander, A. V., Bukchin, B. G., Droznin, D. V., and A.V. Kiryushin (1994), The tectonic environment and source parameters of the Khailino, Koryakiya earthquake of March 8, 1991: Does a Beringia plate exist? Computational Seismology and Geodynamics 
(English edition of the Geodinamika i prognoz zemletriaseniy. Vychislitel'naya seismologiya), 3, 80-96.

Laverov, N. P. (Ed) (2005), Recent and modern volcanism in Russia, Moscow, Nauka Publishers, 604 p. (In Russian)

Le Maitre, R. W., P. Bateman, A. Dudek, J. Keller, M. J. Lameyre Le Bas, P. A. Sabine, R. Schmid, H. Sorensen, A. Streckeisen, A. R. Woolley, and B. Zanettin (1989), A classification of igneous rocks and glossary of terms, Blackwell, Oxford.

Leonov, V. L., E. N. Grib, and L.A. Kartasheva (1990), On the structure and age of Taunshits volcano. Voprosy Geographii Kamchatki, 10, 156-166 (in Russian).

Leonov, V. L., and E. N. Grib (2004), Structural position and volcanism of the Kamchatka Quaternary calderas, 189 p., Dalnauka, Vladivostok.

Levin, V., N. Shapiro, J. Park, and M. Ritzwoller (2002), Seismic evidence for catastrophic slab loss beneath Kamchatka, Nature, 418, 763-767.

Mackey, K. G., K. Fujita, L. V. Gunbina, V. N. Kovalev, V. S. Imaev, B. M. Kozmin, and L. P. Imaseva (1997), Seismicity of the Bering Strait region: evidence for a Bering Block, Geology, 25, 979-982.

Manea, V.C., M. Manea, V. Kostoglodov, and G. Sewell (2005), Thermal models, magma transport and tomographic imaging for the Kamchatka subduction zone, in Plates, Plumes, and Paradigms, edited by G.R. Foulger, J.H. Natland, D.C. Presnall and D.L. Anderson, Geological Society of America Special Volume 388, $861 \mathrm{pp}$,

Map of Mineral Resources of Kamchatka region (1:500 000) [1999].

McElfresh, S. B. Z., W. Harbert, C.-Y. Ku, and J.-S. Lin (2002), Stress modeling of tectonic blocks at Cape Kamchatka, Russia using principal stress proxies from high-resolution SAR: new evidence for the Komandorskiy Block, Tectonophysics, 354, 239-256.

Melekestsev, I.V., 1980. Volcanism and Relief Formation. Moscow: Nauka. 212 pp.

Melekestsev, I. V., O. A.Braitseva, L. D.Sulerzhitsky, N. N.Kozhemyaka, N. V. Ogorodov, I. A.Egorova, and E. G.Lupikina (1971), The age of volcanoes of the Kurile-Kamchatka volcanic region, in Volcanism and the Deep Interior of the Earth, pp. 68-75, Nauka, Moscow (in Russian).

Melekestsev, I. V., O. A. Braitseva, E. N. Erlich, and N. N. Kozhemyaka (1974), Volcanic mountains and plains, in Kamchatka, Kurile and Commander Islands, edited by I. V. Luchitsky, Nauka, Moscow, pp. 162-234, (in Russian).

Melekestsev, I. V., and O. A. Braitseva (1984, English translation 1988), Gigantic rockslide avalanches on volcanoes, Volcanol. Seismol., 6: 495-508.

Melekestsev, I. V., O. A. Braitseva, and V. V. Ponomareva (1989), Prediction of volcanic hazards on the basis of the study of dynamics of volcanic activity, Kamchatka, in Volcanic Hazards Assessment and Monitoring: IAVCEI Proceedings in Volcanology, I. Berlin - ...Tokyo. Springer-Verlag, pp. 10-35.

Melekestsev, I. V., O. N. Volynets, V. A. Ermakov, T. P. Kirsanova, and Yu. P. Masurenkov (1991), Shiveluch volcano, in Active volcanoes of Kamchatka, 1, edited by S. A. Fedotov and Yu. P. Masurenkov, pp. 84-92, Nauka, Moscow.

Melekestsev, I. V., S. N. Litasova, and L. D. Sulerzhitsky (1992), On the age and scale of the directed-blast catastrophic eruption of the Avachinsky volcano (Kamchatka) in the Late Pleistocene, Volcanol. and Seismol., 13(2), 135-146.

Melekestsev, I. V., V. V. Ponomareva, and O. N. Volynets (1995), Kizimen volcano (Kamchatka) - future Mt. St.Helens?, J. Volcanol. Geotherm. Res., 65, 205-226.

Melekestsev, I. V., O. A. Braitseva, L. I. Bazanova, V. V. Ponomareva, and L. D. Sulerzhitsky (1996a), A particular type of catastrophic explosive eruptions with reference to the Holocene subcaldera eruptions at Khangar, Khodutka Maar, and Baraniy Amfiteatr volcanoes in Kamchatka, Volcanol and Seismol., 18, 135-160.

Melekestsev, I. V., O. A. Braitseva, V. V. Ponomareva, and L. D. Sulerzhitsky (1996b), Holocene catastrophic caldera-forming eruptions of Ksudach volcano, Kamchatka, Volcanol. and Seismol., 17, 395-421.

Melekestsev, I. V., O. A. Braitseva, V. V. Ponomareva, and L. D. Sulerzhitsky (1998), A century of volcanic catastrophes in the Kurile-Kamchatka region in Early Holocene time, in Global environmental change, edited by N. L. Dobretsov and V. I. Kovalenko, pp.146-152, Sibir' Division of RAS Publishing House, Novosibirsk

Melekestsev, I. V., O. A. Braitseva, and V. V. Ponomareva (2001), A new approach to defining a term "active volcano", in Geodynamics and Volcanism of the Kurile-Kamchatka Island-Arc System, edited by B. V. Ivanov, pp. 191-203, Petropavlovsk-Kamchatsky, (In Russian).

Melekestsev, I. V., O. A. Braitseva, V. V. Ponomareva, L.I. Bazanova, M. M. Pevzner, and L.D. Sulerzhitsky (2003a), Holocene geological catastrophes at Kamchatka and Kurile islands. Transactions (Doklady) of the Russian Academy of Sciences. Earth science sections, 389/3, 342-345.

Melekestsev, I. V., O. A. Braitseva, V. V. Ponomareva, L.I. Bazanova, Pinegina T.K., and O.V. Dirksen (2003b) AD 0-650 - a period of the strongest natural catastrophes in Kamchatka. Volcanol. and Seismol., (6), 3-23 (In Russian).

Miyashiro, A. (1974), Volcanic rock series in island arcs and active continental margins, Am. J. Sci., 274, 321-355.

Mironov, N. L., M. V. Portnyagin, P. Yu. Pletchov, and S. A. Khubunaya (2001), Final Stages of Magma Evolution in Klyuchevskoy Volcano, Kamchatka: Evidence from Melt Inclusions in Minerals of High-Alumina Basalts. Petrology, 9(1), 46-62.

Münker, C., G. Wörner, G. Yogodzinski, and T. Churikova (2004), Behaviour of high field strength elements in subduction zones: constraints from Kamchatka-Aleutian arc lavas, Earth and Planetary Science Letters, 224, 275-293.

Ogorodov, N. (Ed.) (1972), Volcanoes and Quaternary volcanism of Sredinny Range, Kamchatka, 190 pp., Nauka Publishers, Moscow, (In Russian).

Ozerov, A. Yu. (2000), The evolution of high-alumina basalts of the Klyuchevskoy volcano, Kamchatka, Russia, based on microprobe analyses of mineral inclusions, J. Volcanol. Geotherm. Res., 95, 65-79. 
Park, J., V. Levin, M. Brandon, J. Lees, V. Peyton, E. Gordeev, and A. Ozerov (2002), A dangling slab, amplified arc volcanism, mantle flow and seismic anisotropy in the Kamchatka plate corner, in Plate Boundary Zones, Geodynamics Series, v. 30, edited by S. Stein and J. T. Freymueller, pp. 295-324, Washington, D.C., American Geophysical Union.

Pearce, J. A. (1983), Role of the sub-continental lithosphere in magma genesis at active continental margins, in, Continental basalts and mantle xenoliths; papers prepared for a UK Volcanic Studies Group meeting at the University of Leicester, edited by C. J. Hawkesworth and M. J. Norry, pp. 230-249, Shiva Publ., Nantwich.

Pearce, N. J. G., J. A. Westgate, W. J. Eastwood, and W. T. Perkins (2004), Identification of Aniakchak (Alaska) tephra in Greenland ice core challenges the $1645 \mathrm{BC}$ date for Minoan eruption of Santorini, Geochemistry, Geophysics, Geosystems G3, 5(3), doi: $10.1029 / 2003 \mathrm{GC} 000672$.

Perepelov, A. B. (2004), Neogene-Quaternary shoshonite-latite magmatism of the Kamchatka Sredinny Range: Tekletunup Volcano (geochemistry, petrology, geodynamic interpretation), Volcanol. and Seismol., (4), 1-15, (In Russian).

Perepelov, A. B., A. V. Ivanov, M. Yu. Puzankov and S. I. Dril (2005), Lithospheric control on depth of island-arc magma generation beneath Kamchatka, www. MantlePlumes.org, Discussing the origing of "hotspot" volcanism, http://www.mantleplumes.org/Kamchatka.html

Pevzner, M. M. (2004), The First Geological Data on the Chronology of Holocene Eruptive Activity in the Ichinskii Volcano (Sredinnyi Ridge, Kamchatka). Transactions (Doklady) of the Russian Academy of Sciences/Earth Science Section, 395A(3), p. 335-337.

Pevzner, M. M. (2006), Holocene volcanism of the Northern Kamchatka: space-temporal patterns. Transactions (Doklady) of the Russian Academy of Sciences/Earth Science Section, 409A (6), 884-887.

Pevzner, M. M., Ponomareva, V.V., and I.V.Melekestsev (1998), Chernyi Yar - reference section of the Holocene ash markers at the northeastern coast of Kamchatka, Volcanol. and Seismol., 19(4), 389-406.

Pevzner, M.M., I.V.Melekestsev, O.N.Volynets, and V.A.Melkii (2000), South Cherpuk and North Cherpuk - the largest Holocene monogenetic volcanoes on the Sredinnyi Range of Kamchatka, Volcanol. Seismol. 21, 667-681.

Pevzner, M. M., V. V. Ponomareva, and L. D. Sulerzhitsky (2006), Holocene soil-pyroclastic successions of the Central Kamchatka depression: ages, structure, depositional features, Volcanol. and Seismol., (1), 24-38, (In Russian).

Peyton, V., V. Levin, J. Park, M. T. Brandon, J. Lees, E. I. Gordeev, and A. Ozerov (2001), Mantle flow at a slab edge: Seismic anisotropy in the Kamchatka region, Geophys. Res. Lett., 28, 379-382.

Piip, B. I. (1956), Kliuchevskaya Sopka and Its Eruptions in 1944 1945 and the Past. Trans. Volc. Lab. AN SSSR, Issue 11, (in Russian).

Pinegina, T., J. Bourgeois, L. Bazanova, I. Melekestsev, and O. Braitseva (2003), A millennial - scale record of Holocene tsu- namis on the Kronotskiy Bay coast, Kamchatka, Russia, Quaternary Research, 59, 36-37.

Plank, T., and C. H. Langmuir (1988), An evaluation of the global variations in the major element chemistry of arc basalts, Earth and Planetary Science Letters, 90, 349-370.

Plank, T., and C. H. Langmuir (1993), Tracing trace elements from sediment input to volcanic output at subduction zones, Nature (London), 362, 739-743.

Ponomareva, V. V. (1990), The history of Krasheninnikov volcano and the dynamics of its activity, Volcanol. and Seismol., 9, 714-741.

Ponomareva, V. V., and O. A. Braitseva (1991), Volcanic Hazards Assessment in the Area of lake Kronotskoye, Uzon caldera and Valley of Geysers, Volcanol. and Seismol., 12(1), 42-69.

Ponomareva, V. V., M. M. Pevzner, and I. V. Melekestsev (1998), Large debris avalanches and associated eruptions in the Holocene eruptive history of Shiveluch volcano, Kamchatka, Russia, Bull. Volcanol., 59(7), 490-505.

Ponomareva, V. V., L. D. Sulerzhitsky, O. V. Dirksen, and N. E. Zaretskaia (2001), Holocene paleosols as records of intervals of volcanic quiescence in the Kurile Lake region, South Kamchatka, in "TEPHRAS, chronology, archaeology", Les dossiers de l'Archéologie, (1). CDERAD, edited by E. Juvigné and J. P. Raynal, pp. 91-100.

Ponomareva, V. V., P. R. Kyle, I. V. Melekestsev, P. G. Rinkleff, O. V. Dirksen, L. D. Sulerzhitsky, N. E. Zaretskaia, and R. Rourke (2004), The $7600\left({ }^{14} \mathrm{C}\right)$ year BP Kurile Lake caldera-forming eruption, Kamchatka, Russia: stratigraphy and field relationships, J. Volcanol. Geotherm. Res., 136, 199-222.

Ponomareva, V.V., I. V. Melekestsev, and O. V. Dirksen (2006), Sector collapses and large landslides on Late Pleistocene-Holocene volcanoes in Kamchatka, Russia, J. Volcanol. Geotherm. Res., 158, 117-138.

Ponomareva, V. V., P. R. Kyle, M. M. Pevzner, L. D. Sulerzhitsky, M. Hartman (2007), Holocene eruptive history of Shiveluch volcano, Kamchatka Peninsula, Russia. This volume.

Portnyagin, M., Hoernle, K., Avdeiko, G., Hauff, F., Werner, R., Bindeman, I., Uspensky, V., and D. Garbe-Schönberg (2005), Transition from arc to oceanic magmatism at the KamchatkaAleutian junction, Geology, 33, 25-28.

Portnyagin, M., K. Hoernle, P. Plechov, N. Mironov, and S. Khubunaya (2007a), Constraints on mantle melting and composition and nature of slab components in volcanic arcs from volatiles $\left(\mathrm{H}_{2} \mathrm{O}, \mathrm{S}\right.$, $\mathrm{Cl}, \mathrm{F}$ ) and trace elements in melt inclusions from the Kamchatka Arc, Earth and Planetary Science Letters, 255(1-2), 53-69.

Portnyagin, M., Bindeman, I., Hoernle, K., Hauff, F. (2007b) Geochemistry of primitive lavas of the Central Kamchatka Depression: Magma generation at the edge of the Pacific Plate. This volume.

Prueher, L. M., and D. K. Rea (2001), Tephrochronology of the Kamchatka-Kurile and Aleutian arcs: evidence for volcanic episodicity, J. Volcan. Geotherm. Res., 106, 67-87.

Riegel, S. A., K. Fujita, B. M. Koz 'min, V. S. Imaev, and D. B. Cook (1993), Extrusion tectonics of the Okhotsk plate, northeast Asia, Geophysical Research Letter, 20(7), 607-610. 
Salters, V.J.M. and N.Shimizu (1988), World-wide occurrence of HFSE depleted mantle, Geochim. Cosmochim. Acta, 52, 2177-2182.

Seliverstov, N. I. (1997), Evolution of a junction zone between the Kuril-Kamchatka and Aleutian island arcs: A geodynamic model, Volcanol. and Seismol., 19(3), 269-286.

Selyangin, O. B., O. A. Braitseva, I. A. Egorova, L. D. Sulerzhitsky, I. A. Nesmachny (1979), Geological and tephrochronological studies of recent volcanoes, in Problems of deep magmatism, pp. 31-49, Nauka, Moscow, (in Russian).

Selyangin, O. B., and V. V. Ponomareva (1999), Gorelovsky volcanic center, South Kamchatka: structure and evolution, Volcanol. and Seismol., 21(2), 163-194.

Sheimovich, V. S., and M. I. Karpenko (1997), K-Ar age of volcanism in South Kamchatka, Volcanol. and Seismol., 18(2), 231-236.

Sheimovich, V. S., and D. I. Golovin (2003) Age of the silicic volcanic rocks in the Bolshe-Banny springs region, Volcanol. and Seismol., 1, 21-25, (In Russian).

Sigurdsson, H. (2000), Volcanic episodes and rates of volcanism, in Encyclopedia of Volcanoes, edited by H. Sigurdsson, pp. 271-279, Academic Press, San Diego... Toronto.

Simkin, T., and L. Siebert (1994), Volcanoes of the World. Second edition. 347 p. Geoscience Press, inc. Tucson, Arizona.

Sparks, S. R. J., and H. Sigurdsson (1977), Magma mixing: a mechanism for triggering acid explosive eruptions, Nature, 267, 315-318

Stuiver, M., Reimer, P.J., and Reimer, R.W. (2005), CALIB 5.0 ${ }^{14} \mathrm{C}$ age calibration program, www.calib.org

Sun, S. S., and W. F. McDonough (1989), Chemical and isotopic systematics of oceanic basalts; implications for mantle composition and processes, in Magmatism in the ocean basins. Geological Society Special Publications, edited by A. D. Saunders and M. J. Norry, pp. 313-345, Geological Society of London, London.

Tatsumi, Y., T. Kogiso, and S. Nohda (1995), Formation of a third volcanic chain in Kamchatka; generation of unusual subductionrelated magmas, Contributions to Mineralogy and Petrology, $120,117-128$.

Tsvetkov, A. A., N. G. Gladkov, and O. N. Volynets (1989), Problem of sediment subduction and 10Be isotope in lavas of Kuril Islands and Kamchatka Peninsula, Doklady Akademii Nauk SSSR, 306, 1220-1225.

Turner, S., F. McDermott, C. Hawkesworth, and P. Kepezhinskas (1998), A U-series study of lavas from Kamchatka and the Aleutians: constraints on source composition and melting processes, Contributions to Mineralogy and Petrology, 133, 217-234.

Vlodavets, V.I. (ed) (1957) Catalogue of the active volcanoes of the USSR. In: Bull Volcanol stancii, 25, 180 pp. (in Russian)

Volynets, O. N. (1979), Heterotaxitic lavas and pumices (on the problem of magma mixing), in Problems of Deep Magmatism, edited by V. S. Sobolev, pp. 181-197, Nauka Publishers, Moscow, (In Russian).

Volynets, O. N., V.V. Ponomareva, and A. A. Tsyurupa (1989), Petrological and tephrochronological studies of Krasheninnikov volcano, Kamchatka, Int. Geol. Rev., 31(1), 1107-1122 .
Volynets, O. N., M. G. Patoka, I. V. Melekestsev, and M. I. Zubin (1991), Ichinsky volcano, in Active volcanoes of Kamchatka, edited by S. A. Fedotov and Yu. P. Masurenkov, Vol. 1, pp. 282-294, Nauka, Moscow

Volynets, O. N. (1994), Geochemical types, petrology and genesis of Late Cenozoic volcanic rocks from the Kurile-Kamchatka island-arc system, Int. Geol. Rev. 36(4), 373-405.

Volynets, O. N., V. V. Ponomareva, and A. D. Babansky (1997a), Magnesian basalts of Shiveluch andesite volcano, Kamchatka, Petrology, 5(2), 183-196.

Volynets, O., G. Wörner, A. Babansky, F. Dorendorf, T. Churikova, G. Yogodzinski, Y. Goltsman, and A. Agapova (1997b), Variations in geochemistry and Sr-Nd isotopes in lavas from the Northern Volcanic Group, Kamchatka; evidence for distinct sources at a subducting transform system, Eos, Transactions, F804, American Geophysical Union 78, Washington.

Volynets, O. N., V. V. Ponomareva, O. A. Braitseva, I. V. Melekestsev, and Ch. H. Chen (1999a), Holocene eruptive history of Ksudach volcanic massif, South Kamchatka: evolution of a large magmatic chamber, J. Volcanol. Geotherm. Res., 91, 23-42.

Volynets, O. N., I. V. Melekestsev, V. V. Ponomareva, and J. M. Yogodzinski (1999b), Kharchinsky and Zarechnyi volcanoes, unique centers of Late Pleistocene magnesian basalts in Kamchatka: Composition of erupted rocks, Volcanol. and Seismol., 21(1), 45-66.

Volynets, O. N., A. D. Babanskii, and Yu. V. Gol'tsman (2000), Variations in isotopic and trace-element composition of lavas from volcanoes of the Northern Group, Kamchatka, in relation to specific features of subduction, Geochem. Intern., 38(10), 974-989.

Volynets, A. O. (2006), Pleistocene-Holocene volcanism of Sredinny Range, Kamchatka: rock composition and geodynamic interpretation, Ph. D. thesis, Moscow State University, $195 \mathrm{pp}$.

Volynets A. O., T. G. Churikova, and G. Wörner (2005), Geochemistry of the volcanic rocks of Sredinny Range, Kamchatka, Vestnik KRAUNC, Earth science series, 2(6), 21-33.

Volynets A., Woerner G., Churikova T., and P. Layer (2006), The source of Pleistocene-Holocene volcanism in the Sredinny Range back arc, Kamchatka: constraints from trace elements and isotopic compositions, Abstracts of the 5th Biennial Workshop on Subduction Processes emphasizing the Japan-Kurile-Kamchatka-Aleutian Arcs. Sapporo, Japan, 40-42.

Wallman, P. C., G. A. Mahood, and D. D. Pollard (1988), Mechanical models for correlation of ring-fracture eruptions at Pantelleria, Strait of Sicily, with glacial sea-level drawdown, Bull. Volcanol., 50, 327-339.

Wickman, F. E. (1966), Repose patterns of volcanoes, I. Volcanic eruptions regarded as random phenomena, Ark. Mineral. Geol., 4, 291-301.

Wörner, G., T. Churikova, W. Leeman, V. Liebetrau, S. Tonarini, and A. Heuser (2001), Fluid-Mobile Trace Element and U-series Isotope Variations Across Kamchatka: Timing and effects of slab dehydration, Margins Meeting, Schriftenreihe D. Geol. Ges., 14, 236-237. 
Yogodzinski, G. M., J. M. Lees, T. G. Churikova, F. Dorendorf, G. Woerner, and O. N. Volynets (2001a), Geochemical evidence for the melting of subducting oceanic lithosphere at plate edges, Nature, 409, 500-504.

Yogodzinski, G. M., T. Churikova, A.V. Koloskov, and J. Roth (2001b), Trace element features of subduction-related metasomatism from ultramafic xenoliths of the Kamchatka arc, $A G U$ Fall Meeting, EOS, 82(47), F1199.

Zonenshain, L. P., and L. A. Savostin (1979), Inrtoduction to geodynamics, 311 pp., Nedra, Moscow, (in Russian).
Zaretskaya, N. E., V.V. Ponomareva, and L.D. Sulerzhitsky (2007), Radiocarbon dating of large Holocene volcanic events within South Kamchatka (Russian Far East), Radiocarbon. In press.

Vera Ponomareva, Institute of Volcanology and Seismology, Piip Boulevard, 9, Petropavlovsk-Kamchatsky, 683006, Russia, ponomareva@kscnet.ru 